\author{
P. A. Ziegler · P. Dèzes
}

\title{
Evolution of the lithosphere in the area of the Rhine Rift System
}

Received: 23 October 2003 / Accepted: 1 December 2004/Published online: 31 March 2005

(C) Springer-Verlag 2005

\begin{abstract}
The Rhine Rift System (RRS) forms part of the European Cenozoic Rift System (ECRIS) and transects the Variscan Orogen, Permo-Carboniferous troughs and Late Permian to Mesozoic thermal sag basins. Crustal and lithospheric thicknesses range in the RRS area between $24-36 \mathrm{~km}$ and $50-120 \mathrm{~km}$, respectively. We discuss processes controlling the transformation of the orogenically destabilised Variscan lithosphere into an end-Mesozoic stabilised cratonic lithosphere, as well as its renewed destabilisation during the Cenozoic development of ECRIS. By end-Westphalian times, the major sutures of the Variscan Orogen were associated with $45-60 \mathrm{~km}$ deep crustal roots. During the Stephanian-Early Permian, regional exhumation of the Variscides was controlled by their wrench deformation, detachment of subducted lithospheric slabs, asthenospheric upwelling and thermal thinning of the mantlelithosphere. By late Early Permian times, when asthenospheric temperatures returned to ambient levels, lithospheric thicknesses ranged between $40 \mathrm{~km}$ and $80 \mathrm{~km}$, whilst the thickness of the crust was reduced to $28-35 \mathrm{~km}$ in response to its regional erosional and local tectonic unroofing and the interaction of mantle-derived melts with its basal parts. Re-equilibration of the lithosphere-asthenosphere system governed the subsidence of Late Permian-Mesozoic thermal sag basins that covered much of the RRS area. By end-Cretaceous times, lithospheric thicknesses had increased to $100-120 \mathrm{~km}$. Paleocene mantle plumes caused renewed thermal weakening of the lithosphere. Starting in the late Eocene, ECRIS evolved in the Pyrenean and Alpine foreland by passive rifting under a collision-related north-directed compressional stress field. Following endOligocene consolidation of the Pyrenees, west- and northwest-directed stresses originating in the Alps
\end{abstract}

P. A. Ziegler $(\bowtie) \cdot$ P. Dèzes

Department of Geosciences, Geological-Palaeontological Institute, University of Basel, Bernoullistr. 32, 4056 Basel, Switzerland E-mail: paziegler@magnet.ch

Tel.: + 41-61-4215535

Fax: + 41-61-4215535 controlled further development of ECRIS. The RRS remained active until the Present, whilst the southern branch of ECRIS aborted in the early Miocene. Extensional strain across ECRIS amounts to some $7 \mathrm{~km}$. Plume-related thermal thinning of the lithosphere underlies uplift of the Rhenish Massif and Massif Central. Lithospheric folding controlled uplift of the VosgesBlack Forest Arch.

Keywords Rhine Graben · Rifting · Lithosphere · Stress $\cdot$ Magmatism

\section{Introduction}

The Rhine Rift System (RRS), comprising the northward trending Upper Rhine and Hessian (Wetterau, Leine) grabens and the northwest striking Roer Valley (Lower Rhine) graben, forms the northern branch of the intracontinental European Cenozoic Rift System (ECRIS) that extends over a distance of some 1,100 km from the shores of the North Sea into the Western Mediterranean (Fig. 1; Ziegler 1994). The southern branch of ECRIS includes the grabens of the Massif Central (Limagne, Forez, Roanne), the Bresse Graben and the grabens of the Rhône Valley (Valence, Alès, Manosque, Camarque). The Burgundy transfer zone links the northern and southern segments of ECRIS. A secondary transfer zone links the northern ends of the Limagne and Upper Rhine Grabens via the eastern parts of the Paris Basin. The Eger (Ohre) Graben of the Bohemian Massif forms an integral part of ECRIS. The Rhône Valley grabens find their southern extension in the Gulf of Lions-Valencia rift system, whose development was governed by fundamentally different dynamic processes than those controlling the evolution of ECRIS.

In the ECRIS area the depth to Moho varies between $24 \mathrm{~km}$ and $36 \mathrm{~km}$ (Fig. 2; Prodehl et al. 1995; Dèzes and Ziegler 2002). The thickness of the thermal lithosphere 


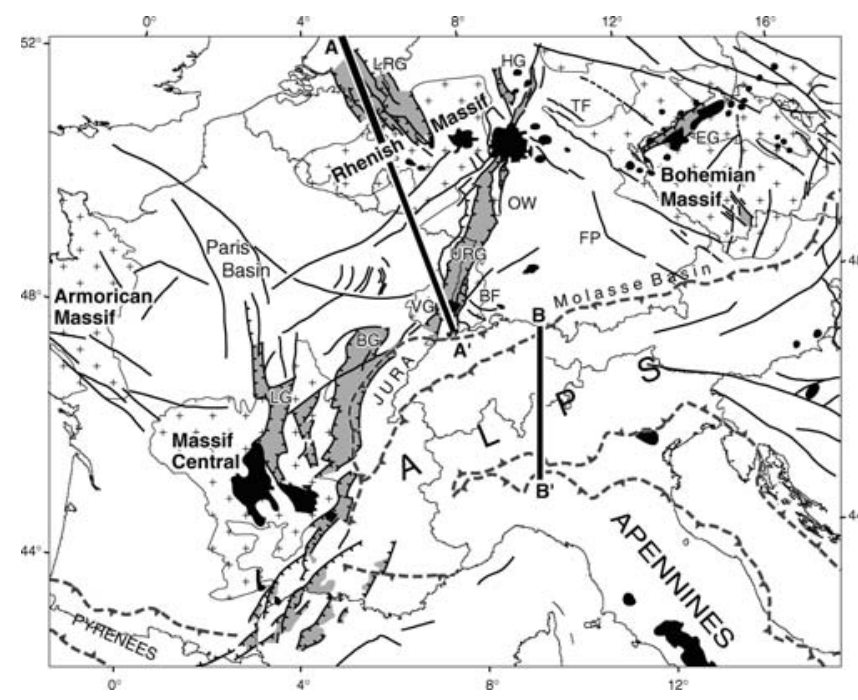

Fig. 1 Location map of ECRIS in the Alpine foreland, showing Cenozoic fault systems (black lines), rift-related sedimentary basins (light grey), Variscan massifs (cross pattern) and Cenozoic volcanic fields (black). Interrupted barbed line: Alpine deformation front. BF Black Forest, BG Bresse Graben, EG Eger (Ore) Graben, FP Franconian Platform; HG Hessian grabens, LG Limagne Graben, LRG Lower Rhine (Roer Valley) Graben, URG Upper Rhine Graben, OW Odenwald; VG Vosges. Thick lines A-A' and B-B': location of transects given in Figs. 4 and 9

decreases from about $100 \mathrm{~km}$ to $120 \mathrm{~km}$ under the Bohemian Massif and along the southern end of the Upper Rhine Graben to 50-60 km beneath the Rhenish Massif and Massif Central and apparently increase to some $120 \mathrm{~km}$ or more in the Western Netherlands and beneath the Paris Basin (Babushka and Plomerova 1992;

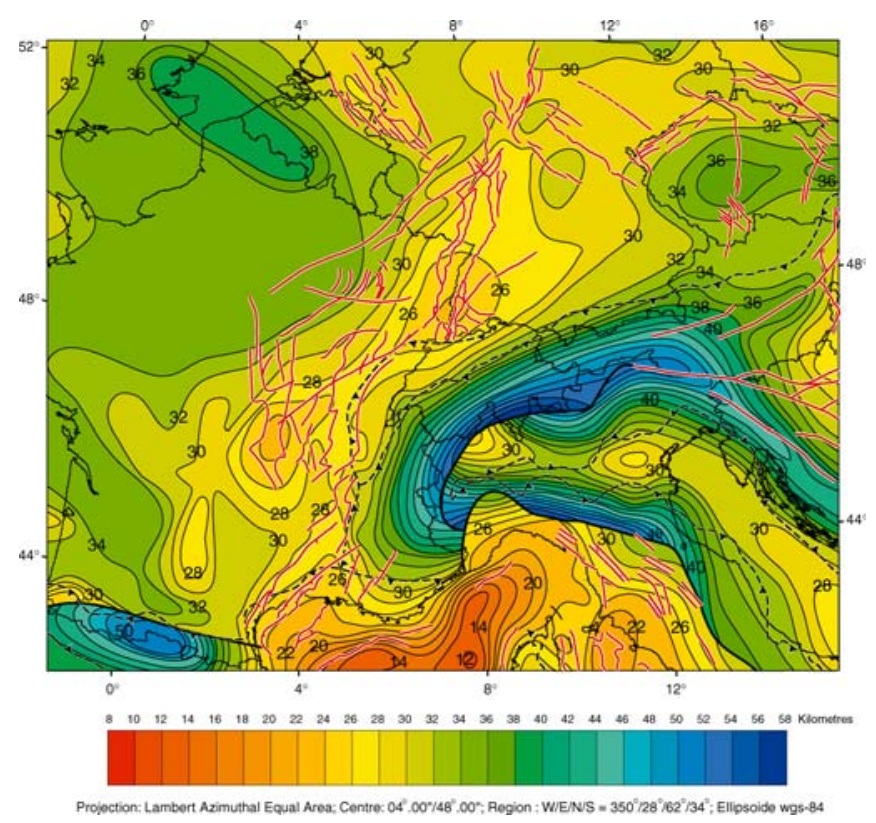

Fig. 2 Depth map of Moho discontinuity, contour interval $2 \mathrm{~km}$ (after Dèzes and Ziegler 2002), with superimposed Cenozoic fault systems. Interrupted barbed line: Alpine deformation front
Prodehl et al. 1995; Sobolev et al. 1997; Goes et al. 2000a, b). In Western and Central Europe the upper asthenosphere displays anomalously low P- and S-wave velocities (Zielhuis and Nolet 1994; Goes et al. 2000a, b). Tomographic images suggest that low velocity structures rising up from the deep mantle feed smaller uppermantle plumes, the most important of which well up beneath the Rhenish Massif and the Massif Central (Granet et al. 1995; Goes et al. 1999; Ritter et al. 2001).

ECRIS transects the essentially SW-NE striking French and German parts of the Variscan Orogen which were, and partly still are, covered by Late Permian and Mesozoic sediments. During the evolution of ECRIS, these sediments were disrupted in conjunction with uplift of the Rhenish Massif, the Vosges-Black Forest Arch, the Massif Central and the Bohemian Massif in which parts of the Variscan Orogen are exposed, thus providing insight into its architecture. This offers a unique opportunity to evaluate the post-Variscan evolution of the lithosphere, particularly as only the southernmost parts of the ECRIS were affected by Mesozoic rifting (Ziegler and Dèzes 2005).

The present crustal and lithospheric configuration of the ECRIS area bears no relationship to the major structural units of the Variscan Orogen but shows affinities with the graben systems and arches that developed during Cenozoic times (Ansorge et al. 1992; Mengel 1992; Ziegler and Dèzes 2005). Yet, development of the Variscan Orogen did involve major crustal shortening and subduction of substantial amounts of supra-crustal rocks, continental and oceanic crust and mantle-lithosphere (Ziegler et al. 1995, 2004). By analogy with the Alps (Schmid et al. 1996; Stampfli et al. 1998), the Variscan Orogen was probably characterised at its end-Westphalian consolidation by a significantly thickened crust and lithosphere. Therefore, its orogenically destabilised lithosphere must have re-equilibrated with the asthenosphere in post-Variscan times to the end that regional crustal and lithospheric thicknesses of about $28-35 \mathrm{~km}$ and $100-120 \mathrm{~km}$, respectively, were achieved, as evident in areas that were not affected by Cenozoic rifting.

During the last $300 \mathrm{Ma}$, the megatectonic setting of the ECRIS area underwent repeated changes. Following the end-Westphalian consolidation of the Variscan Orogen, Stephanian-Early Permian wrench faulting and associated intrusive and extrusive magmatic activity accompanied its collapse. During Late Permian to endCretaceous times, large parts of the ECRIS area were gradually incorporated into intracratonic sedimentary basins that presumably subsided in response to thermal contraction of the lithosphere during its re-equilibration with the asthenosphere. By contrast, Mesozoic rifting, culminating in the Mid-Jurassic opening of the Alpine Tethys, mid-Cretaceous opening of the Bay of Biscay-Valais Basin (Stampfli et al. 1998, 2001) and early Eocene opening of the Arctic-North Atlantic (Ziegler 1988), interrupted these cooling trends and caused a renewed destabilisation of the asthenosphere-lithosphere 
system of shelves flanking these domains (Helvetic, Dauphinois and Atlantic shelves; Ziegler and Stampfli 2001). During the latest Cretaceous and Palaeocene, the entire ECRIS area was affected by an important pulse of intraplate compression that can be related to early phases of the Alpine and Pyrenean orogenies (Ziegler 1990; Ziegler et al. 1995, 1998, 2002). At the same time melilite dykes were injected into the Massif Central, Vosges-Black Forest and Bohemian Massif. This reflects low-degree partial melting of the lithospheric thermal boundary layer at depths of $60-100 \mathrm{~km}$ in response to an increase in the temperature of the asthenosphere (Wilson et al. 1995; Ziegler et al. 1995). From late Eocene times onwards, ECRIS developed in the foreland of the evolving Alpine and Pyrenean orogens, with crustal extension and continued plume activity causing further destabilisation of the lithosphere-asthenosphere system. Under the present northwest-directed stress field the RRS is tectonically still active whereas the grabens of the Massif Central and the Rhône Valley became inactive during the early Miocene (Dèzes et al. 2004; Merle and Michon 2001; Schumacher 2002; Sèranne 1999; Ziegler 1990, 1994).

In this contribution we summarise the results of our studies on processes that controlled the transformation of the orogenically destabilised Variscan lithosphere into cratonic lithosphere, with special emphasis on its configuration prior to the onset of Cenozoic rifting and its response to intraplate stresses and plume activity during the development of ECRIS. A model is presented for the Permo-Carboniferous to end-Mesozoic evolution of the Variscan lithosphere in the RRS area that is based on quantitative and forward modelled subsidence analyses of selected wells (Ziegler et al. 2004). The Cenozoic evolution of the RRS and the Alps is reviewed on the basis of a retro-deformed lithospheric transect that extends from the Central Alps to Amsterdam and supporting palaeotectonic maps (Dèzes et al. 2004). In our analyses we applied the time scale of Menning et al. (2000) and Menning (1995) for the Carboniferous and Permo-Triassic, respectively, the scale of Gradstein and Ogg (1996) for the remainder of the Mesozoic, and the scale of Berggren et al. (1995) for the Cenozoic.

\section{Variscan Orogen}

The RRS transects the suture between the external Rheno-Hercynian and the more internal Saxo-Thuringian zone, as well as the sutures between the Saxo-Thuringian and Bohemian (Moldanubian s.l.) and the Bohemian and Moldanubian (s.s.) zones (Fig. 3). The triple junction of the Upper Rhine, Roer and Hessian grabens is superimposed on the south-dipping Rheno-Hercynian/Saxo-Thuringian suture. The Upper Rhine Graben transects the south-dipping Saxo-Thuringian/Bohemian suture in the northern parts of the Vosges-Black Forest Arch (Lalaye-Lubin and Baden-Baden zone), and the north-dipping Bohemian/

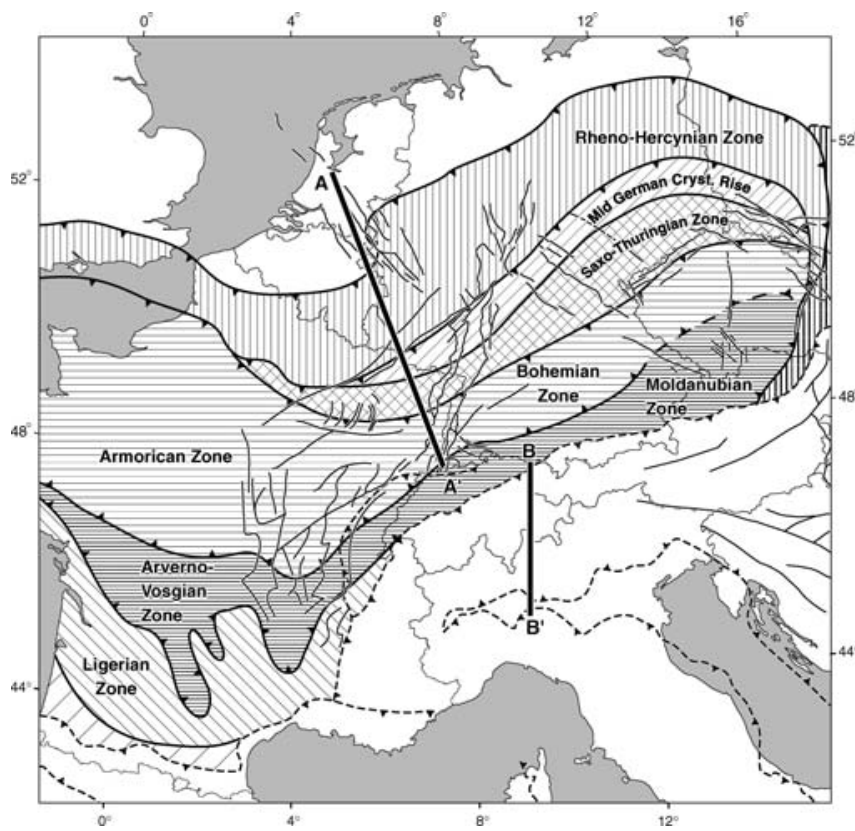

Fig. 3 Variscan tectonic framework with superimposed ECRIS fault pattern (after Ziegler et al. 2004)

Moldanubnian (s.s.) suture in the southern parts of the Black Forest (Badenweiler-Lenzkirch zone) (Eisbacher et al. 1989; Franke 2000; Hegner et al. 2001). To the southwest, this suture links up with the Mt. du Lyonnais suture that is transected by the Bresse Graben and the grabens of the Massif Central (Lardeaux et al. 2001).

At the end-Westphalian termination of the Variscan orogeny, the crustal and lithospheric configuration of the future RRS area was heterogeneous. Whereas the Rheno-Hercynian zone was underlain by continental foreland lithosphere, the Saxo-Thuringian and Moldanubian (s.1.) zones were characterised by an orogenically thickened lithosphere that was thermally destabilised by widespread granitic magmatism. In the internal zones of the Variscan Orogen, crustal thicknesses probably ranged between $45 \mathrm{~km}$ and $60 \mathrm{~km}$ with crustal roots marking the Rheno-Hercynian/Saxo-Thuringian, Saxo-Thuringian/Bohemian and Bohemian/ Moldanubnian sutures. In the area of the Mid-German Crystalline Rise, a major south-dipping continental lithospheric slab extended from the Variscan foreland beneath the Rheno-Hercynian/Saxo-Thuringian suture. A northdipping, partly oceanic subduction slab was probably associated with the Bohemian/Moldanubnian suture, whereas the south-dipping Saxo-Thuringian/Bohemian slab had already been detached from the lithosphere during mid-Visean times (Fig. 4a; Ziegler et al. 2004).

\section{Stephanian-Early Permian disruption of the Variscan Orogen}

During the Stephanian and Early Permian, dextral translation of Gondwana and Laurussia controlled the 

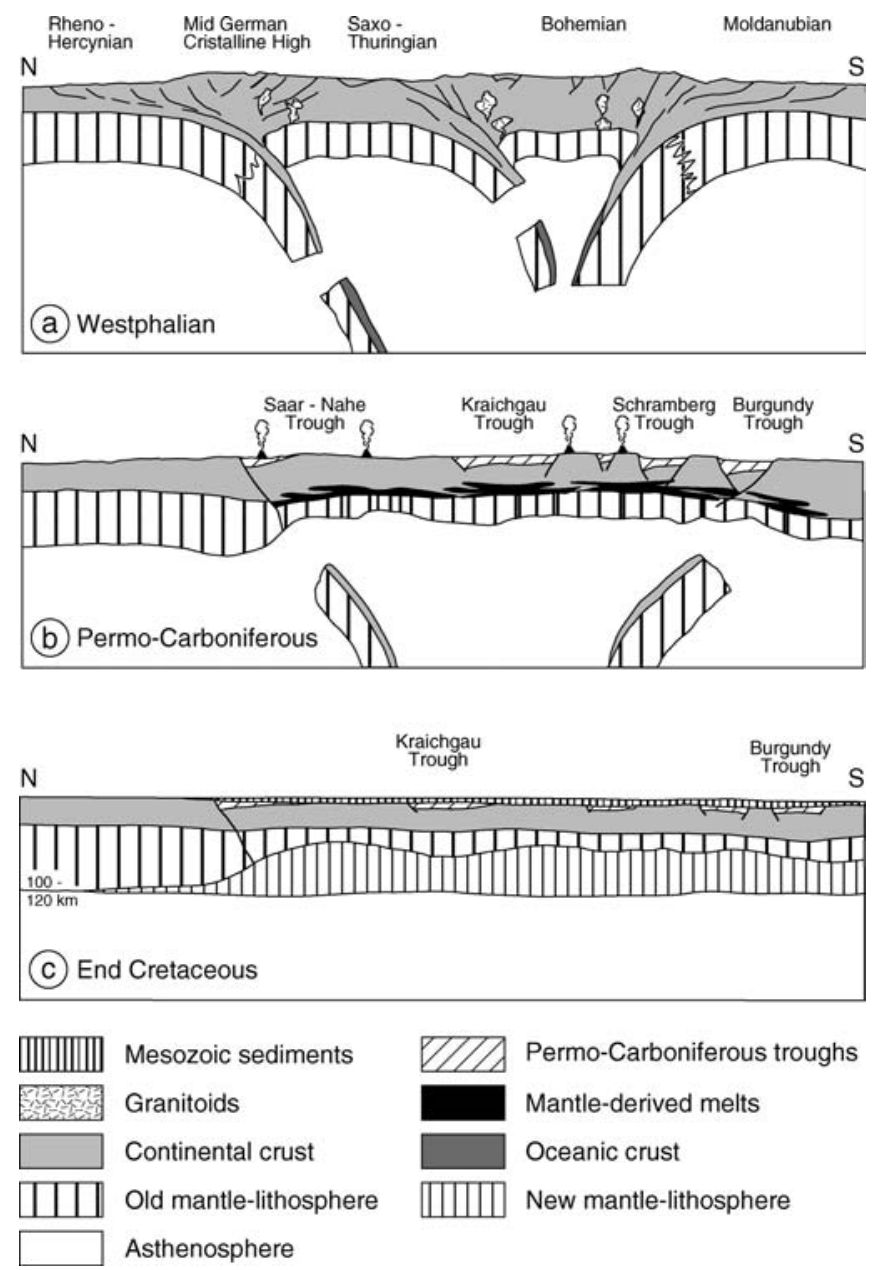

Fig. 4 Conceptual model for Late Palaeozoic and Mesozoic evolution of the lithosphere in the RRS area along transect A-A'(not to scale) (after Ziegler et al. 2004). For location see Fig. 3

evolution of the Appalachian-Mauretanides and Scythian orogens and the wrench-induced collapse of the European Variscan Orogen. Transtensional and transpressional wrench deformation of the Variscan Orogen and its northern foreland, as well as associated magmatic activity, abated at the transition to the Late Permian, in tandem with the consolidation of the Appalachian Orogen (Arthaud and Matte 1977; Ziegler 1989, 1990; Coward 1993; Marx et al. 1995; Ziegler and Stampfli 2001; Ziegler and Dèzes 2005).

Stephanian-Early Permian wrench-induced disruption of the rheologically weak Variscan Orogen was accompanied by its regional exhumation, widespread extrusive and intrusive magmatic activity, peaking during the Early Permian, and the subsidence of a multi-directional array of intramontane transtensional trap-door and pull-apart basins, containing continental clastics (Fig. 5). Basins developing during this time-span underwent a complex, polyphase structural evolution, including a late phase of transpressional deformation controlling their partial inversion. Although Stephanian-Early Permian wrench deformation locally induced

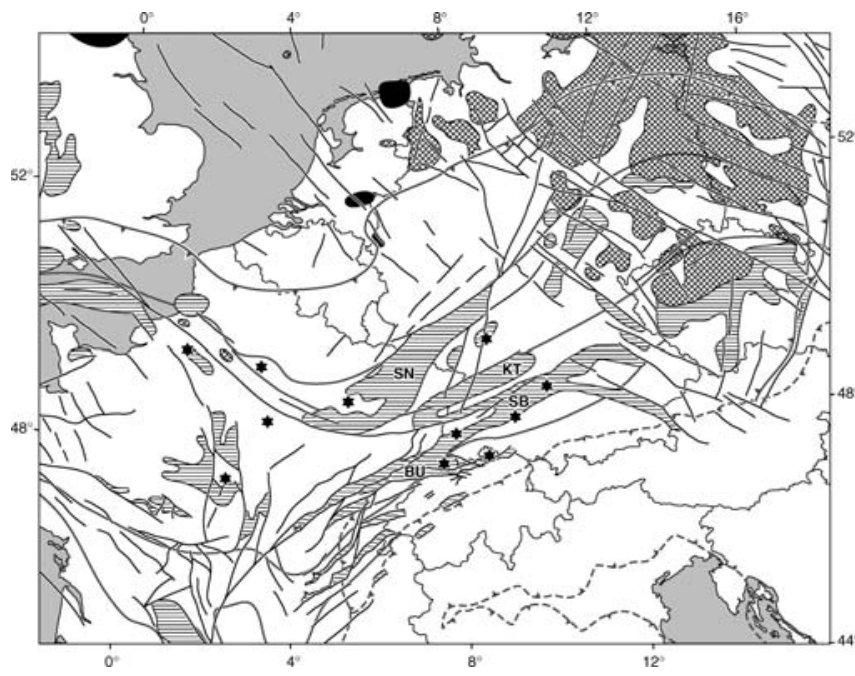

Fig. 5 Stephanian-Early Permian tectonic framework of ECRIS area, showing sedimentary basins (horizontally hatched), major volcanic fields (cross hatched), major sills (black) and fault systems (after Ziegler et al. 2004) with superimposed Variscan tectonic units (solid lines) and Alpine deformation front (interrupted barbed line). Abbreviations: $B U$ Burgundy Trough, $K T$ Kraichgau Trough, $S B$ Schramberg Trough, $S N$ Saar-Nahe Trough. Black dots show location of analysed wells

uplift of extensional core complexes (e.g. Massif Central, Montagne Noire; Vanderhaeghe and Teyssier 2001) and subsidence of often narrow, fault-bounded basins, implying high crustal stretching factors, large intervening areas were not significantly extended (Ziegler 1990; van Wees et al. 2000; Ziegler et al. 2004).

Whilst exhumation of the Variscan internides had commenced already during the main phases of the Variscan orogeny, regional uplift of the entire orogen and its foreland began only after crustal shortening had ceased at the end-Westphalian. Stephanian-Early Permian erosional and tectonic exhumation of the Variscan Orogen, in many areas to formerly mid-crustal levels (Burg et al. 1994; Vigneresse 1999; Seyferth and Henk 2000), can be attributed to such processes as wrench deformation, heating of crustal roots involving eclogite to granulite transformation (Bousquet et al. 1997; Le Pichon et al. 1997), detachment of subducted slabs, upwelling of the asthenosphere and related thermal attenuation and partial delamination of the mantlelithosphere, as well as to magmatic and thermal inflation of the remnant lithosphere (Fig. 4b).

The widespread Stephanian-Early Permian (305$285 \mathrm{Ma})$ alkaline intrusive and extrusive magmatism of the Variscan domain and its foreland is mantle-derived and locally shows evidence of crustal contamination (Bonin 1990; Bonin et al. 1993; Neumann et al. 1995; Marx et al. 1995; Benek et al. 1996; Cortesogno et al. 1998; Breitkreuz and Kennedy 1999; Neumann et al. 2004). Melt generation by partial melting of the uppermost asthenosphere and the lithospheric thermal boundary layer was probably triggered by a rise in the potential temperature of the asthenosphere and by its 
localised transtensional decompression. Wrench-induced detachment of subducted lithospheric slabs presumably caused a reorganisation of the mantle convection system and upwelling of the asthenosphere (Ziegler et al. 2004). Mantle-derived basic melts, which had ascended to the base of the crust and underplated it, induced crustal anatexis and the intrusion of fractionally crystallised granitic to granodioritic-tonalitic melts into the crust, with crustal-scale fractures providing conduits for the ascent of magmas to the surface (Cortesogno et al. 1998; Breitkreuz and Kennedy 1999).

The interaction of mantle-derived basic melts with the felsic lower crust, as well as retrograde metamorphism of the eclogitised crustal roots of the Variscan Orogen (Bousquet et al. 1997), apparently contributed to a re-equilibration of the Moho at depths of $28-35 \mathrm{~km}$ and locally less. By Mid-Permian times, some $30 \mathrm{Ma}$ after consolidation of the Variscan orogen, its crustal roots had disappeared.

During the Stephanian and Early Permian, a system of essentially ENE-WSW trending transtensional intramontane basins developed in the area of the Upper Rhine Graben, whereas NW striking fracture systems transected the Rhenish Massif (Fig. 5). Development of these basins, containing thick continental clastics and volcanics, involved reactivation of the Variscan structural grain, predominantly by dextral shear. The SaarNahe Trough is superimposed on the Rheno-Hercynian/ Saxo-Thuringian terrane boundary and partly on the Saxo-Thuringian/Bohemian suture. The Kraichgau Trough broadly reflects reactivation of the Saxo-Thuringian/Bohemian Lalaye-Lubin-Baden-Baden suture, whereas the Schramberg and Burgundy troughs are associated with the Bohemian/Moldanubnian Lenzkirch-Badenweiler-Mt. du Lyonnais suture. Subsidence of these basins was coupled with uplift and erosion of intervening highs. At the same time, a system of NNESSW trending Variscan shear zones was sinistrally reactivated, partly outlining the Upper Rhine and Hessian grabens (Boigk and Schöneich 1970; Eisbacher et al. 1989; Weber 1995a; Schumacher 2002).

In the area of the Roer and Hessian grabens, postorogenic exhumation of the Rheno-Hercynian thrust belt, prior to the transgression of Late Permian sediments, increased southward from some $2-3 \mathrm{~km}$ along its northern margin to as much as $10 \mathrm{~km}$ adjacent to the Saar-Nahe Basin (Littke et al. 2000; Oncken et al. 2000). Subsidence of this partly inverted basin, which contains up to $5.6 \mathrm{~km}$ of Permo-Carboniferous clastics accounting for a stretching factor of $>1.36$, involved transtensional reactivation of the Rheno-Hercynian/ Saxo-Thuringian and Saxo-Thuringian/Bohemian sutures. Extrusion of voluminous basalts and rhyolites in the Saar-Nahe Basin, dated at 296-293 Ma, reflects profound destabilisation of its lithospheric system (Henk 1993; Stollhofen and Stanistreet 1994; Korsch and Schäfer 1995; Weber 1995b; von Seckendorff et al. 2004). In the area of the Mid-German Crystalline Rise post-kinematic granitic to dioritic magmatism increased during the Stephanian-Early Permian (Schäfer et al. 2000; Thomson and Zeh 2000; Zeh and Brätz 2004).

Strong Stephanian transtensional reactivation of the NE trending German segment of the Rheno-Hercynian/ Saxo-Thuringian suture apparently caused detachment of the subducted continental Rheno-Hercynian lithospheric slab beneath the Mid-German Crystalline Rise; this slab was introduced into the mantle during late Visean to Westphalian times (after mid-Visean detachment of its oceanic part; Ziegler et al. 2004). Upwelling of the asthenosphere into the space formerly occupied by this slab, triggered partial melting of the asthenosphere and the remnant mantle-lithosphere, ascent of melts to the base of the crust and anatexis of lower crustal rocks (model of Davies and von Blanckenburg 1995). In conjunction with an ensuing reorganisation of mantle flow patterns, a not-very-active mantle plume apparently welled up to the base of the lithosphere in the area of the eastern parts of the future Southern Permian Basin, causing thermal attenuation of the mantle-lithosphere and magmatic destabilisation of the crust-mantle boundary (van Wees et al. 2000; Ziegler et al. 2004). A branch of the Southern Permian Basin upwelling system apparently extended from northeast Germany via the Hessian Depression into the area of the Saar-Nahe Trough. This concept is supported by the presence of a distinct middle and lower crustal positive magnetic anomaly that extends from northeast Germany into the area of the Saar-Nahe Trough (Hahn and Wonik 2002); this anomaly probably reflects Permo-Carboniferous permeation of the crust by mantle-derived basic melts. On the other hand, the Rhenish Massif was apparently little affected by magmatic processes but was subjected to regional uplift and erosion, reflecting unflexing of the foreland lithosphere, mainly in response to detachment of the subducted Rheno-Hercynian slab, and perhaps also to retrograde metamorphism of its eclogitised parts.

In the area of the Upper Rhine Graben, StephanianEarly Permian development of a system of ENE-WSW trending intramontane basins (Boigk and Schöneich 1970; Philippe et al. 1996), overlying high-grade metamorphic rocks, reflects transtensional reactivation of the orogenic fabric of the Variscan Internides. Subsidence of these basins and exhumation of intervening highs in response to transtensional lithospheric deformation was accompanied by the intrusion of abundant rhyolite and granite porphyry dikes and the extrusion of Permian rhyolites, reflecting the ascent of mantle-derived partial melts to the base of the crust, lower crustal anatexis and destabilisation of the Moho (Eisbacher et al. 1989; von Raumer 1998; Prijac et al. 2000). Similarly, the widespread occurrence of a reflection-seismically laminated $10-15 \mathrm{~km}$ thick lower crust is mainly attributed to PermoCarboniferous injection of mantle-derived basic sills (Ziegler et al. 2004). In addition, truncation of the crustal orogenic fabric by the Moho (Meissner and Bortfeld 1990) speaks for contemporaneous magmatic destabilisation of the crust-mantle boundary. This reflects a major thermal surge that was presumably triggered by detachment of the 
subducted north-dipping Moldanubian slab in the area of the Lenzkirch-Badenweiler-Mt. du Lyonnais suture (Lardeaux et al. 2001; Ziegler et al. 2004). By end-Early Permian times, the crust of the Variscan Internides had been regionally reduced to $28-35 \mathrm{~km}$ in response to its tectonic and erosional unroofing and magmatic destabilisation of the Moho discontinuity.

In the internal Variscan zones, no mantle reflectors related to subducted crustal material (Ziegler et al. 1998), could be detected despite dedicated surveys (Meissner and Rabbel 1999). This may be an effect of delamination and/or strong thermal thinning of the mantle-lithosphere during the inferred Stephanian-Early Permian thermal surge (Fig. 4b). This is compatible with circumstantial evidence provided by the sedimentary record of Late Permian and Mesozoic basins which subsided in response to re-equilibration of the lithosphere-asthenosphere system (see below).

\section{Late Permian and Mesozoic thermal subsidence and rifting}

By late Early Permian times $( \pm 280 \mathrm{Ma})$, magmatic activity had abated and thermal anomalies introduced during the Permo-Carboniferous began to decay, controlling regional thermal subsidence of the lithosphere. In combination with progressive erosional degradation of the remnant topography and cyclically rising sea levels (Haq et al. 1988), increasingly larger areas subsided below the erosional base-level and were incorporated into a new system of intracratonic basins.

However, in areas bordering the future Tethys and Atlantic domains, thermal subsidence of the lithosphere was overprinted and partly interrupted by the Triassic onset of a new rifting cycle (Ziegler and Stampfli 2001). At the same time a multi-directional rift system developed in Western and Central Europe, comprising the North Sea rift, the Danish-Polish Trough and the graben systems of the Atlantic shelves. Stress fields controlling the evolution of this rift system changed repeatedly in conjunction with the late Middle Jurassic opening of the Alpine Tethys, the Mid-Cretaceous opening of the Valais Trough and the Late Cretaceous concentration of crustal extension on the Arctic-North Atlantic rift (Ziegler 1990; Ziegler et al. 2001).

Although the RRS area was only marginally affected by Mesozoic rifting, minor diffused crustal stretching probably contributed to the subsidence of the Kraichgau, Nancy-Pirmasens, Burgundy and Trier Basins (Fig. 6). Triassic and Jurassic reactivation of PermoCarboniferous faults, controlling subtle lateral facies and thickness changes, is also evident in the Paris Basin (Bessereau et al. 1995; Goggin et al. 1997) and the area of the Burgundy Trough (Wetzel et al. 2003). Mesozoic crustal extension played, however, a more important role in the area of the future Roer Graben that lies in the prolongation of the West Netherlands Basin (Zijerveld et al. 1992), as well as in the area of the Rhône Valley

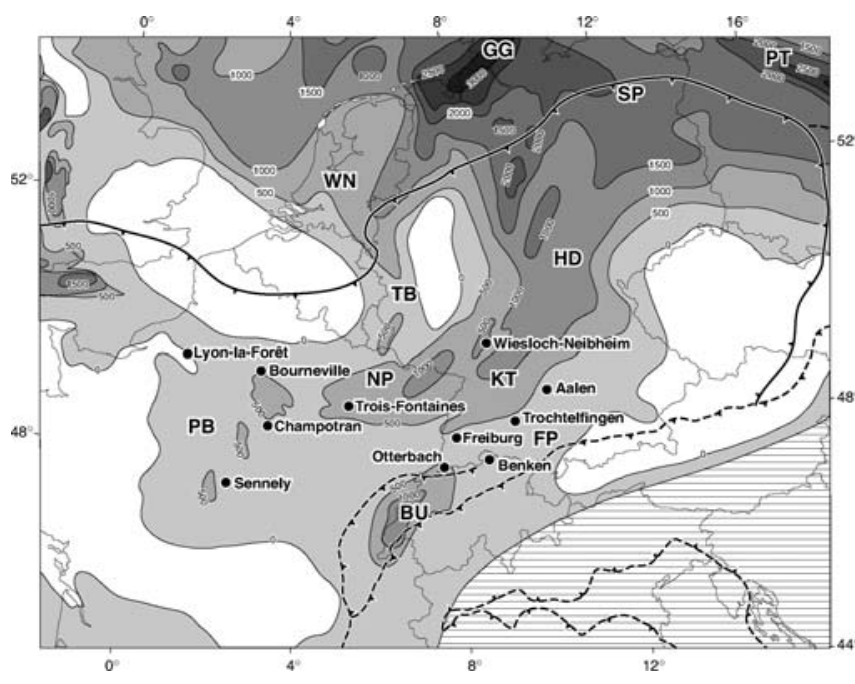

Fig. 6 Isopach map of restored Triassic series, contour interval $500 \mathrm{~m}$, showing location of analysed wells and Variscan (solid barbed line) and Alpine (interrupted barbed line) deformation fronts (after Ziegler et al. 2004). White: areas of non-deposition; horizontally hatched: not mapped area. Abbreviations: $B U$ Burgundy Trough, FP Franconian Platform, GG Glückstadt Graben, $H D$ Hessian Depression, $K T$ Kraichgau Trough, $N P$ Nancy-Pirmasens Trough, $P B$ Paris Basin, $P T$ Polish Trough, SP Southern Permian Basin, $T B$ Trier Basin, $W N$ West Netherlands Basin

grabens that formed part of shelves flanking the Alpine Tethys and Pyrenean-Valais Ocean (Stampfli 1993; Stampfli et al. 2001).

Subsidence analyses on selected wells from the Upper Rhine Graben, the Paris Basin and the Franconian Platform, applying the backstripping method of Sclater and Christie (1980), show that in the RRS area reequilibration of the lithosphere with the asthenosphere commenced during the late Early Permian $( \pm 280 \mathrm{Ma})$ and persisted throughout the Mesozoic (Prijac et al. 2000; van Wees et al. 2000; Ziegler et al. 2004). However, detailed tectonic subsidence curves show that temporary and generally local Mesozoic subsidence accelerations are superimposed on the long-term thermal subsidence trends (Fig. 7). These reflect either tensional reactivation of Permo-Carboniferous fault systems or compressional deflection of the lithosphere (Cloetingh 1988) under farfield rift- and wrench-related stress fields. Temporal and spatial variations in these subsidence accelerations are attributed to differences in the orientation of pre-existing crustal discontinuities and changes in the prevailing stress field. Nevertheless, overall subsidence trends clearly reflect re-equilibration of the lithosphereasthenosphere system trough time.

\section{Tectonic subsidence modelling}

In an attempt to define the configuration of the lithosphere at the end of the Early Permian, the tectonic subsidence curves were compared with a theoretical thermal decay curve, applying an automated numerical 

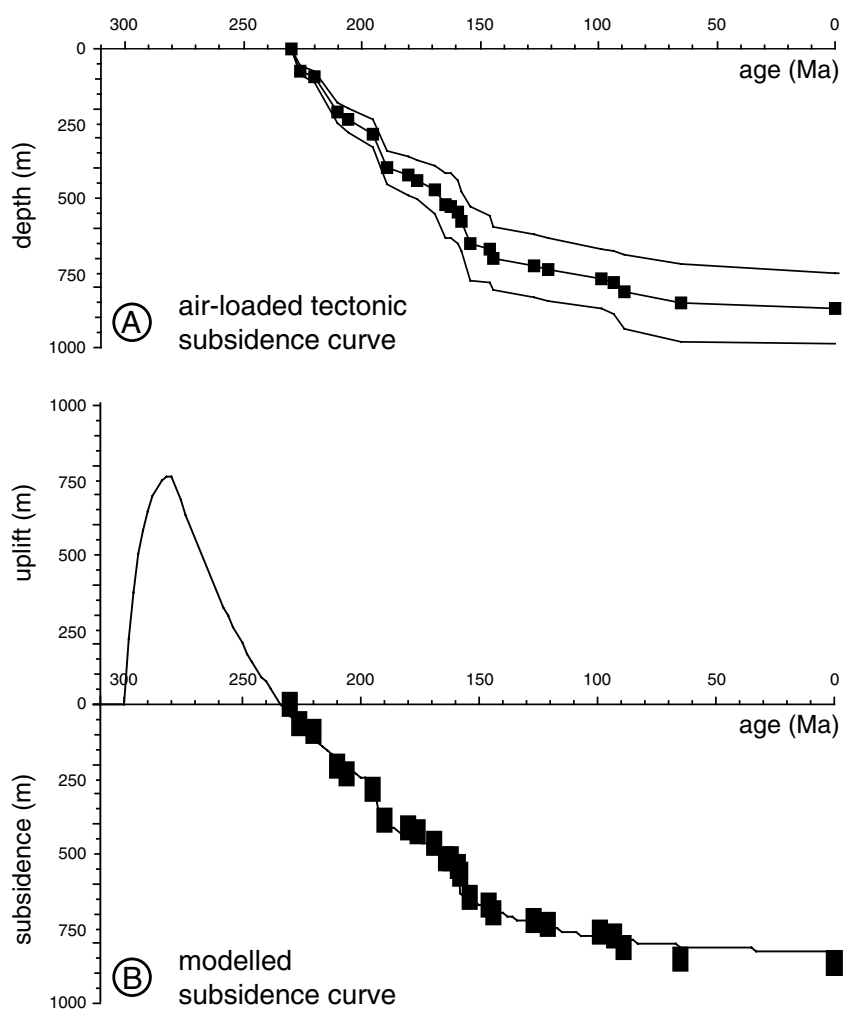

Fig. 7 a Air-loaded tectonic subsidence curve and b modelled subsidence curve for well Bourneville, Paris Basin (after Ziegler et al. 2004). For locations see Fig. 6. Black squares: control points derived from penetrated sedimentary sequence. The positive part of the modelled subsidence curve reflects uplift of the crust in response to thermal thinning and/or delamination of the mantlelithosphere; its negative part reflects thermal subsidence of the crust during re-equilibration of the lithosphere/asthenosphere system

forward/backward modelling technique which automatically finds the best-fit stretching parameters for the observed subsidence data (van Wees et al. 1996, 2000). This modelling technique incorporates lithospheric stretching assumptions ( $\delta$ =crustal, $\beta=$ mantle-lithospheric stretching factor), a lithosphere represented by a plate with constant temperature boundary conditions (fixed basal temperature), crustal heat production effects and conductivity variations, and allows for finite and multiple stretching phases. Differential stretching of the crust and mantle-lithosphere can be applied to simulate thermal attenuation of the latter (van Wees et al. 1992, 1996, 2000; van Wees and Stephenson 1995). Input parameters for forward/backward modelling of observed subsidence curves include the pre-rift crustal thickness, the post-rift equilibrated lithospheric thickness, and for each stretching phase its timing, duration and extension mode (uniform $\delta=\beta$, McKenzie 1978; two-layered $\delta<\beta$, Royden and Keen 1980). The modelled uplift and subsidence history of the lithosphere is then compared to the observed tectonic subsidence curve. In iterative steps input parameters are changed until a good fit is obtained between the observed and modelled curves. This way, best-fit stretching parameters are determined that give a measure of the initial PermoCarboniferous thermal perturbation of the lithosphere, as well as of subsequent tensional events which interfered with the re-equilibration of the lithosphere/ asthenosphere system (Ziegler et al. 2004).

Modelling of the lithosphere evolution in the RRS area assumes that after the Permo-Carboniferous thermal surge (300-280 Ma) the temperature of the asthenosphere returned rapidly to ambient levels $\left(1,300^{\circ} \mathrm{C}\right)$, at least until the end-Cretaceous renewed flare-up of plume activity. Therefore, we assumed for equilibrated thermal lithosphere (Artemieva and Mooney 2001) thicknesses of $100-120 \mathrm{~km}$, which are typical for areas that were not affected by Cenozoic rifting (Babushka and Plomerova 1992). As most of the analysed wells are locate outside or on the margins of Permo-Carboniferous troughs (Fig. 5), initial crustal thicknesses of 30 to $35 \mathrm{~km}$ were considered as representative at the end of Permo-Carboniferous magmatic thinning and erosional unroofing of the crust.

The Permo-Carboniferous tectono-magmatic cycle (300-280 Ma) was modelled with differential crustal and mantle-lithospheric extension, allowing $B$ factors, reflecting delamination and/or thermal thinning of the mantle-lithospheric, to attain significantly greater values than $\delta$ factors. The temporary Mesozoic subsidence accelerations were modelled with uniform lithospheric extension $(\delta=\beta)$. All modelled subsidence curves (Fig. 8; Ziegler et al. 2004) show an initial uplift between $300 \mathrm{Ma}$ and $280 \mathrm{Ma}$, the amplitude of which gives a measure of lithospheric thinning during the StephanianEarly Permian. From $280 \mathrm{Ma}$ onward, the modelled curves reflect thermal subsidence of the lithosphere, the surface of which remained above the erosional base-level until the curves dip below the zero line. From this point onward, the modelled curves are constrained by the tectonic subsidence curves derived from the sedimentary record of the respective wells (black squares in Fig. 7).

Good fits between observed and modelled tectonic subsidence curves were obtained, assuming initial crustal thicknesses of 30-35 km, final lithospheric thicknesses of 100-120 km, and a Permo-Carboniferous "stretching" phase spanning 300-280 Ma, involving decoupled crustal extension and mantle-lithospheric attenuation. This assumption is compatible with the concept that PermoCarboniferous crustal extension played only locally a significant role. Indeed, large Permo-Carboniferous troughs, which occur on the Massif Central, the Bohemian Massif and the Franconian Platform do not coincide with Late Permian and Mesozoic depocentres, whereas no major Permo-Carboniferous sedimentary troughs underlay the Southern Permian Basin and Paris Basin depocentres (Ziegler 1990). This suggests that during the Permo-Carboniferous tectono-magmatic cycle uniform and/or depth-dependent mechanical stretching of the lithosphere was, on a regional scale, only a contributing and not the dominant mechanism of crustal and mantle-lithospheric thinning. By contrast, 

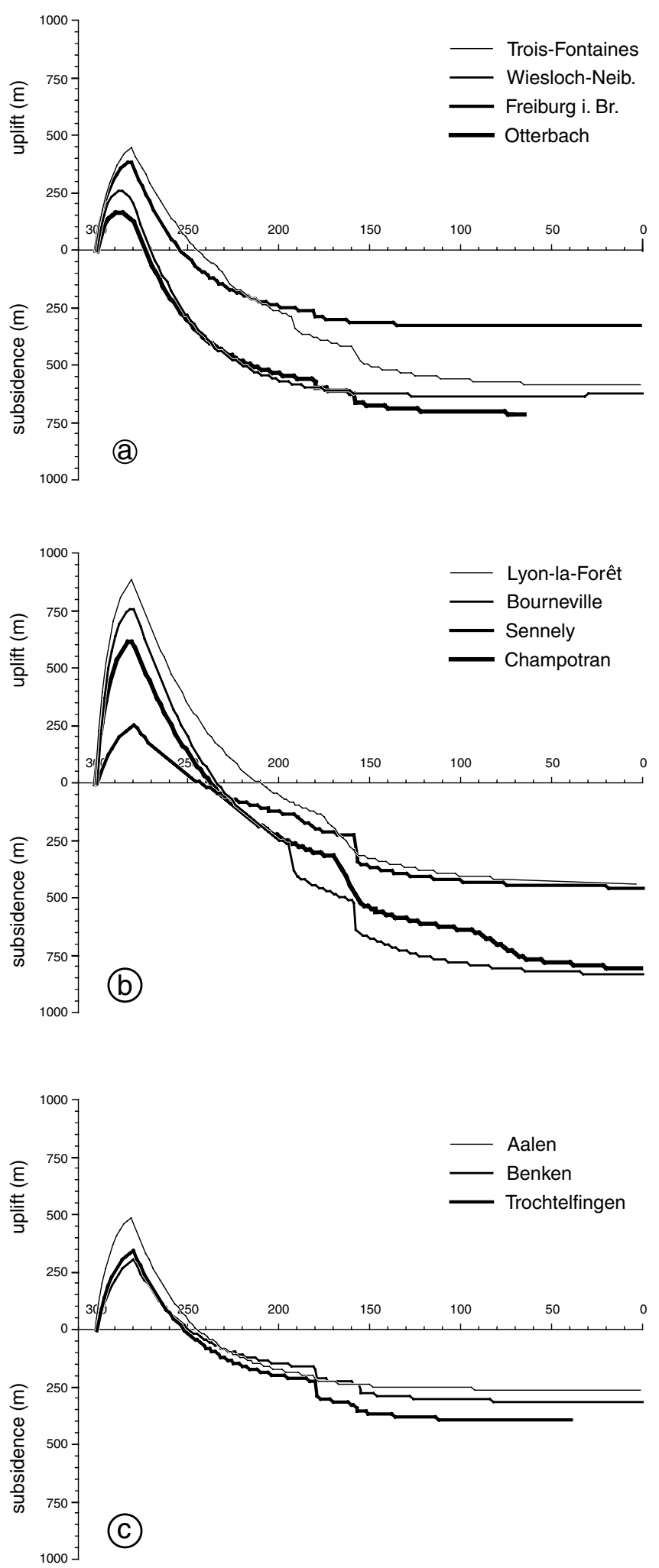

Fig. 8 Modelled subsidence curves for a Upper Rhine Graben and Lorraine area, b Paris Basin and c Franconian platform (after Ziegler et al. 2004). For location of wells see Fig. 6

Permo-Carboniferous lithospheric stretching may have played a somewhat more important role in the Late Permian and Mesozoic evolution of the Hessian
Depression, Nancy-Pirmasens and Burgundy Trough. However, the axes of these basins are only partly aligned with Permo-Carboniferous troughs and partly even cross cut them (compare Figs. 5, 6).

In accordance with the concept that, after the PermoCarboniferous thermal surge, the temperature of the asthenosphere had returned to ambient levels by late Early Permian times, the modelled tectonic subsidence curves demonstrate that from then onward the evolution of the lithosphere in the RRS area was governed by the long-term decay of thermal anomalies. Moreover, modelled curves suggest that by late Early Permian times the thermal thickness of the mantle-lithosphere had been reduced to between $9 \mathrm{~km}$ and $48 \mathrm{~km}$ and that crustal thicknesses ranged between $27 \mathrm{~km}$ and $34 \mathrm{~km}$ (Table 1, Fig. 4b; Ziegler et al. 2004).

Calculated $B$ factors are subject to large variations and reflect heterogeneous mantle-lithosphere thinning that was generally more intense in areas that evolved into Mesozoic depocentres than in areas marginal to them. However, in areas which remained positive features through much of Mesozoic times, such as the Bohemian and Armorican Massifs, the mantle-lithosphere was apparently not significantly thinned during the Permo-Carboniferous, retained a thickness of 50 $90 \mathrm{~km}$ and an orogen (subduction)-related anisotropy (Babushka and Plomerova 2001; Judenherc et al. 2002). Best-fits between observed and modelled subsidence curves were obtained when the thickness of the thermal lithosphere was set at 100 or $120 \mathrm{~km}$ at its end-Mesozoic equilibration with the asthenosphere (Fig. 4c). For the Upper Rhine Graben and the Franconian Platform bestfits were obtained with a $100-\mathrm{km}$ thick lithosphere, whereas for the Paris Basin best-fits were achieved with a lithosphere thickness of $120 \mathrm{~km}$. Whilst a $100 \mathrm{~km}$ lithosphere thickness is compatible with the Palaeocene plume-related segregation depth of olivine-melilitic partial melts in the Vosges, Black Forest and Bohemian Massif (Wilson et al. 1995), no explanation can be given for the apparently greater lithosphere thickness beneath the Paris Basin.

Although $B$ factors given in Table 1 must be considered as rough approximations only, substantial Permo-Carboniferous thinning of the mantle-lithosphere provided the principal driving mechanism for the subsidence of Late Permian and Mesozoic thermal sag basins in the RRS area. On a regional scale, modelled Permo-Carboniferous crustal extension was relatively low, with automated modelling yielding $\delta$ factors of 1.04-1.13 and crustal thicknesses close to the actual ones (assuming initial crustal thicknesses of $30-35 \mathrm{~km}$ ). The minor, intra-Mesozoic subsidence accelerations, which overprint the long-term thermal subsidence curves, were successfully modelled by uniform lithospheric extension, yielding cumulative $\delta=\beta$ values in the 1.01-1.07 range. As corresponding extensional faulting is generally poorly documented, stress-induced deflections of the lithosphere (Cloetingh 1988) may have contributed to some of these temporary subsidence accelerations. 
Table 1 Input parameters and modelling results for Permo-Carboniferous thermal destabilisation of the lithosphere

\begin{tabular}{|c|c|c|c|c|c|c|c|}
\hline \multirow{2}{*}{$\begin{array}{l}\text { Basin } \\
\text { Well name }\end{array}$} & \multicolumn{2}{|c|}{ Input } & \multicolumn{2}{|c|}{ Calculated } & \multicolumn{3}{|c|}{ End-Early Permian } \\
\hline & EL & $\mathrm{IC}$ & $\beta$ & $\delta$ & RML & $\mathrm{RC}$ & RL \\
\hline \multicolumn{8}{|l|}{ Paris Basin } \\
\hline Lyon-la-Foret & 120 & 35 & 10.00 & 1.04 & 8.5 & 33.6 & 42.1 \\
\hline Bourneville & 120 & 35 & 9.99 & 1.08 & 8.5 & 33.4 & 41.9 \\
\hline Champotran & 120 & 35 & 5.08 & 1.07 & 17.0 & 33.0 & 50.0 \\
\hline Sennely & 120 & 35 & 1.77 & 1.03 & 48.1 & 34.0 & 82.1 \\
\hline \multicolumn{8}{|c|}{ Lorraine and Rhine Graben area } \\
\hline Trois-Fontaines & 120 & 35 & 3.06 & 1.06 & 27.8 & 33.0 & 60.8 \\
\hline Wiesloch-Neibsh & 100 & 30 & 5.79 & 1.13 & 12.1 & 26.5 & 38.6 \\
\hline Freiburg & 100 & 30 & 3.89 & 1.06 & 18.0 & 28.3 & 46.3 \\
\hline Otterbach & 100 & 30 & 3.72 & 1.12 & 18.8 & 26.7 & 45.5 \\
\hline \multicolumn{8}{|c|}{ Franconian platform } \\
\hline Benken & 100 & 30 & 2.42 & 1.04 & 28.9 & 28.8 & 57.7 \\
\hline Trochtelfingen & 100 & 30 & 3.02 & 1.05 & 23.2 & 28.6 & 51.8 \\
\hline Aalen & 100 & 30 & 4.49 & 1.04 & 15.6 & 28.8 & 44.4 \\
\hline
\end{tabular}

$E L$ equilibrated lithosphere thickness in $\mathrm{km} ; I C$ initial crustal thickness in $\mathrm{km} ; \mathrm{B}$ mantle-lithospheric attenuation factor; $\delta$ crustal stretching factor; $R M L$ remnant mantle-lithosphere thickness in km; $R C$ remnant crustal thickness in km; $R L$ remnant lithosphere thickness in $\mathrm{km}$

\section{Paleocene to Mid-Eocene ECRIS pre-rift stage}

During the latest Cretaceous and Paleocene, subsidence of Mesozoic sedimentary basins that had developed in the RRS area was interrupted and the entire area was uplifted and subjected to erosion. This is attributed to the build-up of intraplate compressional stresses that were projected from the Alpine and Pyrenean orogens into their northern foreland. However, continued subsidence and sedimentation characterised the Paris Basin and parts of the North Sea and North German Basins (Ziegler 1990).

By Paleocene times, southward subduction of the Piemont (Alpine Tethys) Ocean beneath the AustroAlpine orogenic wedge was apparently completed, resulting in collision of the latter with the continental Briançonnais Terrane, which since the Cenomanian (90 Ma) formed part of the European plate (Fig. 9a; Stampfli et al. 1998, 2001; Schmid et al. 2004). Owing to subduction resistance of the Briançonnais Terrane, compressional stresses were transmitted through it and the Valais Ocean into the northward adjacent Helvetic Shelf and the domain of the future RRS. These stresses induced broad-scale warping and uplift of the European lithosphere, causing the development of a regional erosional unconformity, and, by reactivation of pre-existing faults, inversion of the West-Netherlands and SaarNahe basins. The most distal Paleocene inversion structures are located in the central North Sea, some $1,700 \mathrm{~km}$ to the northwest of the contemporaneous Alpine collision front (Ziegler 1990; Ziegler et al. 1998, 2002).

Similarly, in the foreland of the Western Alps and Pyrenees, the Dauphinois Shelf and the Massif Central were uplifted and subjected to erosion during the Paleocene in response to the build-up of compressional intraplate stresses originating at the Pyrenean collision zone (Vergés and García-Senez 2001) and sinistral shear motions between the Briançonnais Terrane and the Iberian micro-continent during their separation. Related far-field stresses are held responsible for early inversion movements in the Paris Basin and Channel area (Ziegler 1988, 1990; Ziegler et al. 2002; Dèzes et al. 2004).

Paleocene compressional deformation of the Alpine and Pyrenean forelands was accompanied by the injection of olivine-nephelinite and olivine-melilite dykes in the area of the Massif Central, the Vosges-Black Forest, the Rhenish Massif and the Bohemian Massif, reflecting very low degree partial melting of the lithospheric thermal boundary layer and an asthenospheric source at depths of 60-100 (Wilson et al. 1995; Ziegler et al. 1995; Adamovic and Coubal 1999; Ulrych et al. 1999; Michon and Merle 2001; Keller et al. 2002). This suggests that the temperature of the asthenosphere had increased in these areas during the Paleocene, presumably in response to activation of a system of not-very-energetic mantle plumes (Granet et al. 1995; Sobolev et al. 1997; Ritter et al. 2001; Ziegler et al. 2004). Significantly, this distinctly pre-rift magmatic activity in the ECRIS area essentially coincided with the activation of the NE Atlantic (Hoernle et al. 1995) and Iceland plumes (Ziegler 1990; Bijwaard and Spakman 1999). Thus, it is likely that development of the broad thermal anomaly, that is now evident at the base of the West and Central European lithosphere (Zielhuis and Nolet 1994; Goes et al. 2000a, b), commenced during the Paleocene, causing thermal weakening of the lithosphere and thus rendering it prone to deformation (Ziegler et al. 1995). During the early and middle Eocene, scattered pre-rift volcanic activity continued in the Upper Rhine Graben area (Keller et al. 2002), on the Rhenish Massif (Lippolt 1983) and on the Bohemian Massif (Ulrych et al. 1999).

During the early Eocene, northward convergence of the Alpine orogenic wedge with its European foreland accelerated (Schmid and Kissling 2000). With this, 
imbrication of the upper crust and sedimentary cover of the Briançonnais Terrane and the Valais Ocean and subduction of their lower crust and mantle lithosphere commenced (Fig. 9b; Schmid et al. 1996; Stampfli et al. 1998). Sediment subduction accounted for mechanical decoupling of the Alpine orogenic wedge and the European lithosphere, as evidenced by the end-Paleocene relaxation of compressional intraplate stresses in the Alpine foreland (Ziegler 1990; Ziegler et al. 2002). Slab- and thrust-loaded flexural subsidence of the Helvetic and Dauphinois shelves began during the middle Eocene (Burkhard and Sommaruga 1998; Lickorish and Ford 1998; Sissingh 2001). In the Pyrenees, continued early and middle Eocene crustal shortening (Vergés and GarcíaSenez 2001) was accompanied by the main deformation phase of the Languedoc-Provençal thrust belt (Fig. 10a; Roure and Colletta 1996).

During the middle Eocene, isolated, shallow depressions developed in the area of the Upper Rhine, Bresse and Valence grabens and on the Massif Central in which, generally thin fluvio-lacustrine sediments were deposited; these are separated by a hiatus from the late Eocene earliest syn-rift deposits (Sissingh 1998, 2001, 2003). It is uncertain whether development of these depressions can be attributed to an initial rifting phase (shallow lithospheric necking level, Kooi et al. 1992), which was controlled by the gradual build-up of northdirected compressional foreland stresses (Fig. 10a).

\section{Late Eocene initial rifting stage of ECRIS}

By late Eocene times, the lithosphere of the Briançonnais and the Valais Ocean had been subducted and subduction of the Helvetic Shelf commenced whilst crustal slices of the Briançonnais and Valais Ocean were incorporated into the Alpine orogenic wedge (Fig. 9c). Continued thrust- and slab-loaded subsidence of the Helvetic and Dauphinois shelves caused rapid widening of the flexural foreland basin (Schmid et al. 1996; Stampfli et al. 1998; Burkhard and Sommaruga 1998; Lickorish and Ford 1998; Dèzes et al. 2004).

Increasing subduction resistance of the European lithosphere was coupled with imbrication of the basement of the distal Helvetic Shelf (Subpenninic Adula nappe: Schmid et al. 1996) and the build-up of northward-directed intraplate compressional stresses in the Alpine foreland. In the ECRIS area these stresses interfered constructively with northward-directed compressional stresses emanating from the Pyrenean collision zone (Bergerat 1987; Ziegler 1994; Séranne 1999; Merle and Michon 2001). This stress field controlled the late Eocene early rifting phases of the Upper Rhine Graben during which Late Variscan and Permo-Carboniferous crustal discontinuities were transtensionally reactivated (Sissingh 1998; Schumacher 2002). Similarly, late Eocene activation of the Massif Central, Bresse and Valence grabens involved tensional reactivation of Permo-Carboniferous fracture systems (Michon and Merle 2001; Sissingh 2001).
By contrast, contemporaneous development of the Lower Rhône Valley grabens involved transtensional reactivation of the Provençal thrust belt and of underlying Mesozoic extensional fault systems (Roure and Colletta 1996; Sanchis and Séranne 2000).

Volcanic activity associated with the initial rifting stage of the Upper Rhine Graben (Lippolt 1983; Keller et al. 2002) indicates gradual assertion of the Rhenish mantle plume (Ritter et al. 2001). Whereas during the late Eocene volcanic activity increased on the Bohemian Massif (Ulrych et al. 1999), there is no evidence for time equivalent volcanism on the Massif Central (Michon and Merle 2001).

At the Eocene-Oligocene transition far-field compressional stresses governed the second inversion phase of the West-Netherlands Basin (Ziegler 1990; de Lugt et al. 2003).

\section{Oligocene-early Miocene main rifting stage of ECRIS}

At the Eocene-Oligocene transition, the subducted lithospheric slab of the Central and Eastern Alps was detached from the foreland lithosphere within the Helvetic margin (Fig. 9d; Davies and von Blanckenburg 1995; Schmid et al. 1996). Subsequently, the Alpine orogenic wedge continued to converge with the European foreland, but now in a northwest direction (Schmid and Kissling 2000). Development of the Apulian mantle back-stop accounted for strong collisional coupling between the Central Alpine orogenic wedge and its northern and southern forelands, as evidenced by backfolding of the entire orogen and further imbrication of the European foreland crust (e.g. Gotthard Massif; Schmid et al. 1996). On the other hand, the subducted lithospheric slab of the Western Alps remained attached to the European foreland. Continued Oligocene crustal shortening caused back folding of the West Alpine orogenic wedge and emplacement of nappes derived from the Valais Ocean, Briançonnais Terrane and Piemont Ocean on the Dauphinois Shelf (Lickorish and Ford 1998; Fügenschuh and Schmid 2003; Bucher et al. 2003). By end Oligocene times, the Alpine deformation front was located some $100 \mathrm{~km}$ to the south of the Upper Rhine Graben and about $100 \mathrm{~km}$ to the east of the Bresse Graben.

North-directed compressional stresses, projected into the European foreland from the Alpine and Pyrenean collision zones, controlled the Oligocene main extensional phase of ECRIS (Fig. 10b; Bergerat 1987). During the Rupelian, rifting propagated from the Upper Rhine Graben northward into the Hessian and Roer Valley grabens (Ziegler 1990; Schumacher 2002; Michon et al. 2003). Similarly, the grabens of the Massif Central and Rhône Valley subsided rapidly during the Oligocene and coalesced. This was coupled with further sinistral motions along the Burgundy transfer zone that links the Limagne and Bresse Grabens with the Upper Rhine Graben (Bergerat 1977; Ziegler 1994; Merle and Michon 
2001) and the activation of the more diffuse eastern Paris Basin transfer zone that links the Limagne Graben with the northern end of the Upper Rhine Graben (Coulon 1992). Intermittent Oligocene marine connections between the Alpine foreland basin and the North German Basin via the grabens of ECRIS indicate that by this time the Rhenish Massif and the Massif Central were still located close to sea level (Ziegler 1990, 1994; Michon and Merle 2001; Merle and Michon 2001; Sissingh 1998, 2001, 2003). However, increasing volcanism in the area of the Rhine-Roer-Hessian graben triple junction, and late Oligocene gradual uplift of the Rhenish Massif probably reflect increased activity of the Rhenish mantle plume and related thermal thinning of the mantle-lithosphere (Lippolt 1983; Jung 1999; Ritter et al. 2001). By contrast, on the Massif Central, scattered volcanic activity resumed only during the late Oligocene (Michon and Merle 2001). During the early and middle Oligocene, the Bohemian Massif was affected by a major phase of volcanism that essentially preceded subsidence of the NE striking Eger Graben (Malkovsky 1987; Adamovic and Coubal 1999; Ulrych et al. 1999).

During the late Rupelian and Chattian, the grabens of the lower Rhône Valley propagated southward across the eastern, by now inactive, parts of the Pyrenean Orogen into the Gulf of Lions and into coastal Spain (Fig. 10b). The evolving Gulf of Lions-Valencia Trough rift system remained active until crustal separation was achieved during the late Aquitanian (21.5 Ma) and the oceanic Provençal-Ligurian Basin began to open. Development of this rift system was driven by back-arc extension related to eastward roll back of the subducted Alpine Tethys slab that dipped beneath Corsica-Sardinia and the Balearic islands (Séranne 1999; Roca 2001).

Early and middle Oligocene north-directed compressional stresses emanating from the active central Pyrenean Orogen (Vergés and García-Senez 2001) played a dominant role in controlling the main extensional stage of ECRIS. These "Pyrenean" stresses interfered constructively in the RRS area with north-directed compressional stresses originating in the Central Alps (Fig. 10b; Bergerat 1987; Schumacher 2002). By contrast, subsidence of the northeast striking Eger Graben, that contains $300-400 \mathrm{~m}$ thick late Oligocene-early Miocene sediments, commenced only towards the end of its main magmatic pulse, presumably in response to the collapse of a thermal dome (Malkovsky 1987; Adamovic and Coubal 1999). During the late Oligocene, lithospheric shortening compensating for Africa-Europe convergence, was gradually transferred from the Pyrenean collision zone to the Corsica-Sardinia-Balearic arc-trench system. With this, "Pyrenean" intraplate compressional stresses gradually relaxed in the European foreland, whilst roll-back of the Alpine Tethys slab controlled the late Oligocene-early Miocene development of the Gulf of Lions-Valencia Trough rift system (Séranne 1999; Roca 2001). Conversely, we question whether slab-pull forces exerted by the southeast- to east-dipping West-Alpine subduction system contrib-
Fig. 9 Conceptual model for Cenozoic evolution of the lithosphere in the RRS area along transect A-B' (after Dèzes et al. 2004). For location see Fig. 1

uted to the Oligocene subsidence of the Massif Central, Bresse and Valence grabens, which subparallel the Western Alps, as postulated by Stampfli et al. (1998), Merle and Michon (2001) and Michon et al. (2003). In this respect it should be kept in mind that the late Oligocene-early Miocene pulse of basin inversion affecting the Western Shelves, the Channel and Paris Basin (Fig. 10b) can be attributed to the build up of collision-related, northwest-directed compressional stresses in the foreland of the Western Alps (Ziegler 1990; Ziegler et al. 1995, 1998, 2002) and minor westward rotation of France in response to crustal extension across ECRIS (Dèzes et al. 2004)

\section{Miocene response of ECRIS to Alpine compression}

Imbrication of the external massifs of the Western and Central Alps commenced during the Burdigalian (Fig. 9e; Schmid et al. 1996; Fügenschuh and Schmid 2003). Progressive uplift of these massifs was accompanied by the propagation of thin-skinned thrusts into the Helvetic and Dauphinois shelves and ultimately into the domain of the Jura Mountains (Schmid et al. 1996; Burkhard and Sommaruga 1998; Lickorish and Ford 1998; Philippe et al. 1996, 1998). From the Burdigalian onward, increased collisional coupling of the Alpine Orogen with its northern and western forelands had clear repercussions on the evolution of ECRIS (Fig. 10c).

During the Miocene, the Roer Valley Graben and the northern parts of the Upper Rhine Graben continued to subside under a northwest-directed compressional stress field (Schumacher 2002; Michon et al. 2003), whereas the Rhenish Massif, including the Hessian grabens, was gradually uplifted and became the site of increased volcanic activity (Lippolt 1983; Jung 1999; Sissingh 2003). This is attributed to progressive thermal thinning of the mantle-lithosphere above the increasingly active Rhenish plume (Ritter et al. 2001).

Uplift of the Vosges-Black Forest Arch commenced during the Burdigalian (Fig. 10c; Laubscher 1992). In a $\mathrm{N}-\mathrm{S}$ direction and at the top-basement level, the amplitude of this arch is about $2.5 \mathrm{~km}$ and its wavelength some $200 \mathrm{~km}$ with a steeper southern and a gentler northern flank. At the level of the Moho, this arch forms the culmination of broadly southwestnortheast trending anticlinal feature, which extends from the Massif Central via the Burgundy transfer zone towards the Bohemian Massif (Fig. 2; Dèzes and Ziegler 2002). As the Vosges-Black Forest Arch is not associated with mantle-lithospheric thinning (Achauer and Masson 2002), its development is attributed to 

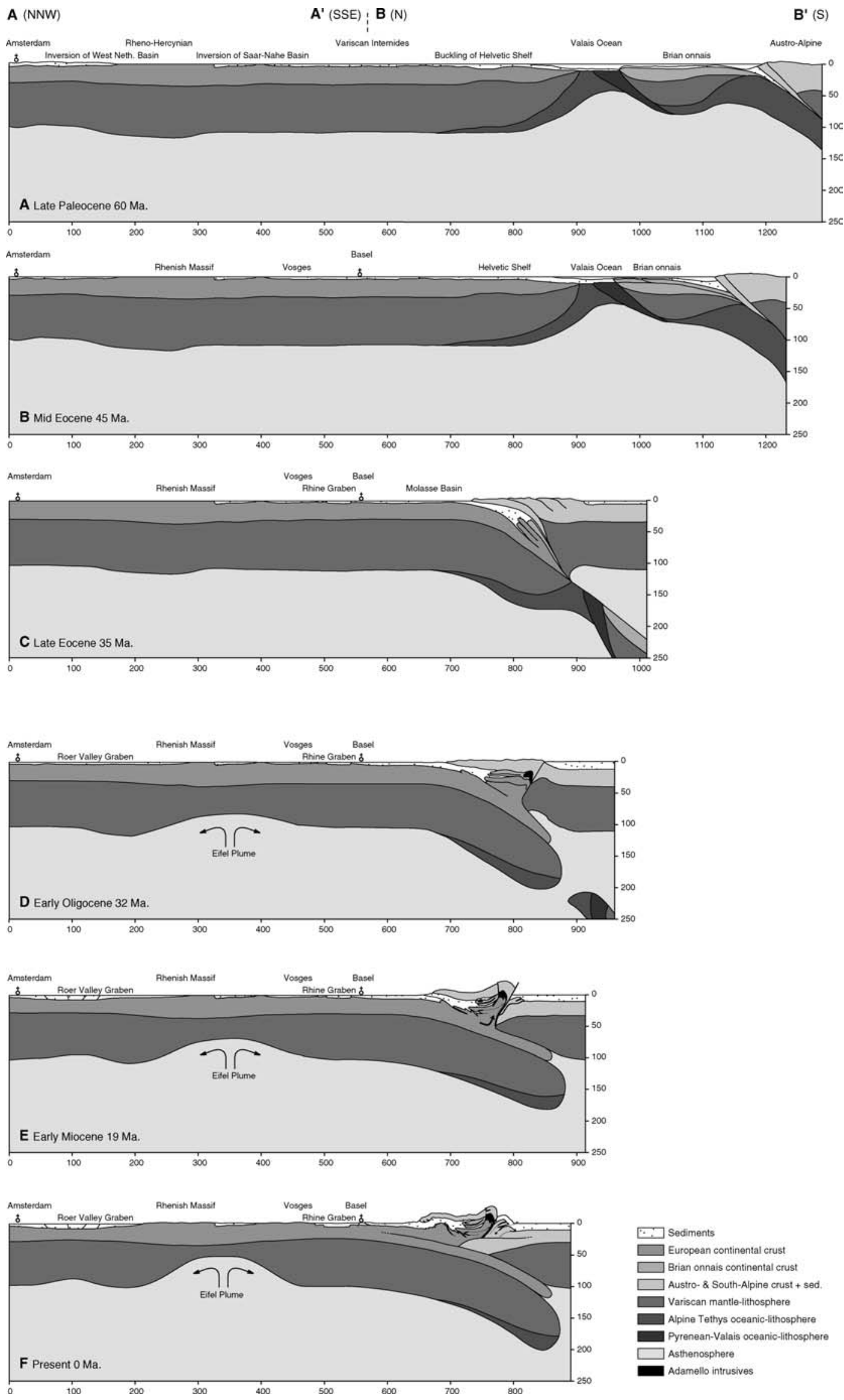

$\because$ Sediments

$\square$ European continental crust Brian onnais continental crust

$\square$ Austro- \& South-Alpine crust + sed

$\square$ Variscan mantle-lithosphere

Alpine Tethys oceanic-lithosphere

Pyrenean-Valais oceanic-lithosphere

$\square$ Asthenosphere

Adamello intrusives 

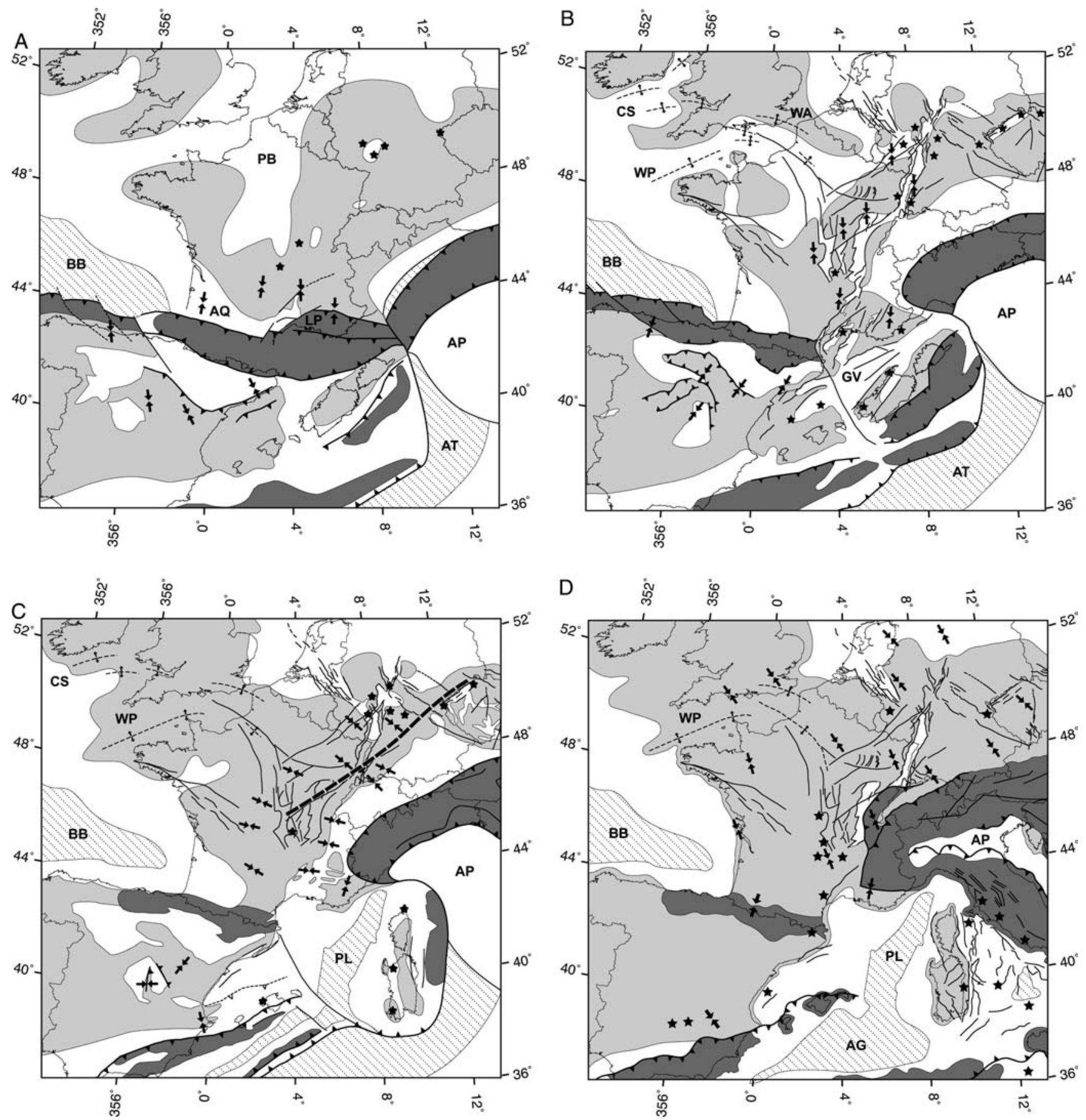

Fig. 10 Palaeotectonic sketch maps of ECRIS area. a middle Eocene, b late Oligocene, c end early Miocene, d Pliocene-Quaternary (modified after Dèzes et al. 2004). Dark grey orogens; light grey areas of non-deposition; white sedimentary basins; stippled oceanic basins; stars volcanism; arrows maximum horizontal compressional stress direction (after: Bergerat 1987; Blès and Gros 1991; Schumacher 2002; Andeweg 2002); thick dashed line axis of lithospheric fold. Abbreviations: $A G$ Algerian Basin, $A P$ Apulia, $A T$ Alpine Tethys, $B B$ Bay of Biscay, $C S$ Celtic Sea, $G V$ Gulf of Lions-Valencia rift, $L P$ Languedoc-Provençal fold belt, $P B$ Paris Basin, $P L$ Provençal-Ligurian Basin, $W A$ Weald-Artois axis, WP Western Approaches

lithospheric folding. End-Aquitanian (20.5 Ma) transpressional reactivation of pre-existing basement discontinuities at the southern end of the Upper Rhine Graben (Laubscher 2003) reflects the build-up of compressional stresses at crustal levels, heralding uplift of the Vosges-
Black Forest Arch. Uplift of this arch was accompanied by volcanic activity within and outside the Upper Rhine Graben, spanning 18-7 Ma (Jung 1999; Keller et al. 2002), reflecting low-degree decompressional partial melting of the asthenosphere and the lithospheric ther- 
mal boundary layer. Development of the Vosges-Black Forest Arch commenced around $18 \mathrm{Ma}$, continued during the late Miocene to early Pliocene thin-skinned folding phase of the Jura Mountains (10-4 Ma; Laubscher 1986, 1992; Philippe et al. 1996; Becker 2000), and was coupled with uplift of the southern parts of the Upper Rhine Graben, causing deep truncation of its Oligocene-early Miocene syn-rift sediments (Roll 1979; Villemin et al. 1986; Sissingh 1998; Schumacher 2002; Dèzes et al. 2004). Whereas Miocene and early Pliocene crustal extension across the Upper Rhine Graben controlled continued subsidence of its northern parts, lithospheric folding-related uplift over-compensated for the extensional subsidence of its southern parts.

Marine connections between the Upper Rhine Graben, the Molasse and North Sea basins were severed during the Burdigalian and end-Langhian, respectively (Sissingh 2003), owing to lithospheric folding in the area of the Burgundy transfer zone and the Vosges-Black Forest and thermal doming of the Rhenish Massif. From the Serravallian onward, the erosional base-level in the Upper Rhine Graben was controlled by the elevation of tectonic sills separating it from adjacent basins.

Miocene NW-SE extension across the Eger Graben intensified after $18 \mathrm{Ma}$, when sediment accumulation in this basin ended (Adamovic and Coubal 1999) and uplift of the northern parts of the Bohemian Massif commenced, presumably in response to lithospheric folding.

In the Bresse Graben, an intra-Burdigalian $( \pm 18 \mathrm{Ma})$ erosional unconformity, that is overstepped by thin Serravallian and younger series (Séranne 1999; Sissingh 1998, 2001), can be attributed to lithospheric folding along the Burgundy transfer zone. Uplift and northward tilting of the Massif Central commenced during the Burdigalian, controlling the development of its north-directed drainage system. With this, its grabens ceased to subside (Merle et al. 1998; Michon and Merle 2001; Sissingh 2001). On the Massif Central, volcanic activity increased during the middle Miocene (14 Ma), shifted to its southern parts and reached a first peak during the late Miocene (9-6 Ma) (Michon and Merle 2001). Plume-related thinning of the mantle-lithosphere presumably played a dominant role in the gradual uplift of this massif (Sobolev et al. 1997; Michon and Merle 2001), with lithospheric folding playing a subordinate role.

The grabens of the Lower Rhône Valley became inactive with the late Aquitanian (21.5 Ma) onset of seafloor spreading in the Provençal-Ligurian Basin that ended during the late Burdigalian (16.5 Ma; Séranne 1999; Roca 2001). The Manosque and Alès grabens were partly inverted during the Miocene (Roure and Colletta 1996; Sanchis and Séranne 2000), reflecting the build-up of a westerly-directed, collision-related compressional stress field (Fig. 10c; Blès and Gros 1991). Similarly, further inversion of the Paris, Channel and Western Approaches basins during the late Miocene testifies to the build-up of compressional stresses in the distal foreland of the Western Alps (Ziegler 1990).

\section{Neotectonic deformation of the RRS}

In the Western and Central Alps, crustal shortening persisted during the Pliocene and Quaternary, as evidenced by continued uplift of their external massifs (Jouanne et al. 1998; Fügenschuh and Schmid 2003) and further compressional deformation of the Jura Mountains (Fig. 9e; Philippe et al. 1996; Giamboni, et al. 2003) and the Dauphinois (Martinod et al. 1996; Lickorish and Ford 1998). Neotectonic activity within the Alps and their foreland is documented by seismicity (Giglia et al. 1996; Deichmann et al. 2000; Schmid and Kissling 2000) and by geodetic data that indicate present-day shortening rates of $2-5 \mathrm{~mm} / \mathrm{y}$ for the Dauphinois and French Jura Mountains (Jouanne et al. 1995; Martinod et al. 1996). From about $4 \mathrm{Ma}$ onward, compressional deformation of the Jura Mountains was no longer exclusively thin-skinned but involved also the basement, as indicated by intra-crustal earthquakes (Roure et al. 1994; Philippe et al. 1996; Jouanne et al. 1998; Becker 2000). During the Pliocene, frontal elements of the Jura fold-and-thrust belt encroached on the margins of the Upper Rhine and the Bresse grabens.

Under the present north- to northwest-directed compressional stress regime (Müller et al. 1997) the Roer Valley graben is extending nearly orthogonally, whereas the Upper Rhine and lower Rhône Valley grabens are subjected to sinistral transtension (Fig. 10d; Ahorner 1975; Giglia et al. 1996; Hinzen 2003). Pliocene and Quaternary extensional and transtensional subsidence of the Roer Valley and Upper Rhine grabens, respectively, is documented by the fault-controlled thickness of their sedimentary fill, the occurrence of active faults and earthquake activity (Ahorner 1983; Zijerveld et al. 1992; Plenefisch and Bonjer 1997; Schumacher 2002; Michon et al. 2003). By contrast, there is no evidence for further subsidence of the Massif Central grabens (Michon and Merle 2001), whereas the Bresse Graben was tensionally reactivated during the Pliocene (Sissingh 1998; Dèzes et al. 2004). In the Rhône Valley minor Pliocene-Quaternary normal faulting has been recorded (Blès and Gros 1991).

During the late Pliocene $(2.9 \mathrm{Ma})$ the palaeo-Aare river, which from 4.2 Ma onwards had flowed westward along the Jura thrust front into the Bresse Graben (Sundgau gravels), was deflected into the Upper Rhine Graben (Müller et al. 2002; Giamboni et al. 2003). This may be attributed to a resumption of tensional subsidence of the southern parts of the Upper Rhine Graben, combined with decreasing uplift rates of the VosgesBlack Forest Arch. Geodetic data show for the Black Forest a pattern of slow uplift of horst- and slow subsidence of graben-structures at rates rarely exceeding $0.25 \mathrm{~mm} / \mathrm{y}$ (Müller et al. 2002). In the area of the Rhenish Massif, volcanic activity shifted during the Pliocene and Quaternary towards the Eifel area (Lippolt 1983). Geomorphologic data indicate that uplift of the Rhenish Massif accelerated around 0.8 Ma, amounting 
since then up to $250 \mathrm{~m}$ (Garcia-Castellanos et al. 2000; Meyer and Stets 2002). In the Eifel area, recent uplift rates of up to $1.2 \mathrm{~mm} / \mathrm{y}$ have been recorded (Mälzer et al. 1983). Processes contributing to this uplift presumably include the thermal load of the Eifel plume (radius $50 \mathrm{~km}$; Ritter et al. 2001; Garcia-Castellanos et al. 2000), thermal thinning of the mantle-lithosphere, and possibly also crustal scale folding and reactivation of Variscan thrust faults under the prevailing NW-directed compressional stress field (Ahorner 1983; Hinzen 2003). Beneath the volcanic fields of the Rhenish Massif the lithosphere has been thermally thinned to $50-55 \mathrm{~km}$ (Prodehl et al. 1995).

High-resolution reflection-seismic data indicate that the northern parts of the Upper Rhine Graben subsided continuously during Miocene to Quaternary times. South of the city of Speyer, late Miocene and Pliocene fluvial and lacustrine series progressively overstep the intra-Burdigalian unconformity, that had developed in conjunction with uplift of the Vosges-Black Forest Arch, so that sedimentation in the southern parts of the Upper Rhine Graben resumed only during the late Pliocene and Quaternary (Roll 1979). Syn-sedimentary extensional faults and local positive flower-structures (Strasbourg transfer zone) were active during the Plio-Quaternary subsidence of the Upper Rhine Graben (see also Illies et al. 1981).

During the late Pliocene (2.9-1.65 Ma) the sediment load of the Rhine River was effectively trapped in the Upper Rhine Graben, indicating that sediment supply was in balance with the development of accommodation space by extensional graben subsidence and tectonic controls on the erosional base-level. During the late Pliocene, the Upper Rhine Graben was drained northward by a low energy river (Bingen-Koblenz Rhine) that linked up with the higher energy Moselle River which crossed the Rhenish Massif and debouched into the Roer Valley Graben where the Kieseloolite sands and gravels were deposited (Brunnacker and Boenigk 1983; Klett et al. 2002; Sissingh 2003). At the end of the Pliocene $(1.65 \mathrm{Ma})$ the first arrival of Alpine detrital components in the Roer Valley Graben (Boenigk 2002; Heumann and Litt 2002) indicates that sediment supply to the Upper Rhine Graben apparently exceeded its subsidence rates. During the Quaternary, the erosional base-level of the continuously subsiding Upper Rhine Graben was controlled by the uplift-rate of the Rhenish Massif and the incision-rate of the Rhine River. The present erosional base-level of the Upper Rhine Graben is located $80 \mathrm{~m}$ above MSL at the entrance to the Rhine canyon.

Neotectonic activity in the southern parts of the Upper Rhine Graben is documented by the deformation of the Pliocene Sundgau gravels and Pleistocene terraces along the Jura Mountains thrust front (Giamboni et al. 2004), by faults extending through Quaternary deposits of the graben fill, and by the seismicity of the area. Earthquake focal mechanisms indicate strike-slip to compressional deformation of the upper crust, whereas the lower crust is subjected to extension (Plenefisch and Bonjer 1997; Deichmann et al. 2000). Transpressional deformation of the upper crust is attributed to collisionrelated stresses transmitted from the Alps above an incipient mid-crustal detachment level. Lower crustal extension may be related to buckling of the mantlelithosphere, controlling slow uplift of the Vosges-Black Forest Arch, in response to the transmission of compressional stresses from the Alps through the mechanically strong parts of the mantle-lithosphere.

Uplift of the Bohemian Massif, presumably in response to lithospheric folding (Ziegler et al. 2002; Dèzes et al. 2004), continued during the Pliocene and Quaternary and was marked by the resumption of volcanic activity (Ulrych et al. 1999; Michon and Merle 2001). Lithospheric thicknesses decrease from $100 \mathrm{~km}$ beneath the northern and southern flanks of the Bohemian Massif to $80 \mathrm{~km}$ under the Eger Graben (Babushka and Plomerova 2001). This may be attributed to thermal thinning of the mantle-lithosphere during the Oligocene main volcanic phase of this area, causing weakening of the lithosphere and thus localisation of the postulated lithospheric fold. Yet, a mantle-plume support of the Bohemian Massif Arch cannot be excluded.

Minor Pliocene and Quaternary crustal extension across Upper Rhine Graben was accompanied by sinistral movements along the Burgundy transfer zone and a tensional reactivation of the Bresse Graben. This is compatible with the seismicity of the Burgundy transfer zone (Giglia et al. 1996). At the Miocene-Pliocene transition, the frontal thrust sheet of the Jura Mountains overrode the eastern margin of the Bresse Graben by $3.5 \mathrm{~km}$. This thrust is sealed by Pliocene clastics that are up to $400 \mathrm{~m}$ thick in the central parts of this graben (Sissingh 2001). The corresponding accommodation space was probably provided by a mild tensional reactivation of the Bresse Graben and not so much by its incorporation in a flexural Alpine foreland basin, as postulated by Merle et al. (1998). A tensional model for the Pliocene subsidence of the Bresse Graben is compatible with the occurrence of extensional faults within the thrust sheet that had overridden its complex eastern border fault zone across which its sole is warped down by 80 m (Chauve et al. 1988; Guellec et al. 1990; Roure et al. 1994). At present, the Bresse Graben is subjected to uplift and erosion (Sissingh 1998, 2001).

On the Massif Central, volcanism intensified at the transition to the Pliocene (5.5 Ma), reached a second peak between $4 \mathrm{Ma}$ and $0.5 \mathrm{Ma}$ and is presently subactive (Michon and Merle 2001). From about 3.5 Ma onward, uplift of the Massif Central accelerated (Michon and Merle 2001) and still continues at rates of up to $1.75 \mathrm{~mm} / \mathrm{a}$ with differential movements occurring between blocks delimited by ENE-trending fractures (Lenôtre et al. 1992). Under the present NW-directed stress field the Massif Central is subjected to transtensional deformation (Fig. 10d; Delouis et al. 1993). This stress field came into evidence during the Pliocene upon decay of the Miocene W-directed West-Alpine 
compressional stresses (Blès and Gros 1991). Progressive plume-related uplift and northward tilting of the Massif Central apparently counteracted transtensional subsidence of its graben system. Beneath the central parts of the Massif Central the lithosphere has been thermally thinned to 55-60 km (Sobolev et al. 1997).

\section{Extensional strain across ECRIS and crustal configuration}

Extensional strain derived from upper crustal faulting amounts to about $2 \mathrm{~km}$ across the Bresse Graben and 3$4 \mathrm{~km}$ across the grabens of the Massif Central and does not exceed $7 \mathrm{~km}$ across the Upper Rhine Graben. Across the Roer Valley Graben, extensional strain diminishes from 4-5 km in the southeast to zero near the Dutch North Sea coast. However, assuming uniform pre-rift crustal thicknesses, the crustal configuration of the Roer Valley, Upper Rhine and Limagne grabens suggests a 2-3times greater extensional strain (Geluk et al. 1994; Brun et al. 1992; Bergerat et al. 1990; Merle et al. 1998).

ECRIS is characterised by a broad belt of Moho shallowing that cannot be exclusively attributed to Cenozoic crustal extension, thermal uplift of the Massif Central and Rhenish Massif and lithospheric folding in the area of the Burgundy transfer zone and the VosgesBlack Forest and Bohemian Massif arches. Therefore, it is likely that in the ECRIS area crustal thicknesses were not uniform at the onset of Cenozoic rifting, owing mainly to lateral variations in the intensity of PermoCarboniferous crustal thinning (see e.g. western part of Massif Central in Fig. 2) and Mesozoic crustal extension (e.g. Roer Valley Graben; Ziegler and Dèzes 2005). Nevertheless, Cenozoic crustal extension across ECRIS entailed a minor clock-wise rotation of France that may have contributed to the inversion of Mesozoic extensional basins in the Channel-Western Approaches area, involving reactivation of northwest-trending PermoCarboniferous shears that transect the Armorican Massif and Paris Basin (Dèzes et al. 2004).

\section{Conclusions}

In the wider RRS area, the following sequence of dynamic processes controlled the transformation of the over-thickened crust and lithosphere of the Variscan Orogen to present-day crustal and lithospheric thicknesses:

1) Stephanian-Early Permian wrench faulting caused disruption of the Variscan Orogen, detachment of subducted lithospheric slabs and upwelling of the asthenosphere, giving rise to widespread mantle-derived magmatic activity. During this thermal surge, partial delamination and thermal thinning of the mantle-lithosphere, thermal inflation of the remnant lithosphere and interaction of mantle-derived partial melts with the lower crust accounted for the destruction of the 45-60 km deep crustal roots of the Variscan Orogen and its regional uplift. By end-Early Permian times the crust was thinned down on a regional scale to $27-35 \mathrm{~km}$, mainly by magmatic processes and erosional unroofing and only locally by mechanical stretching, whilst the thickness of the mantle-lithosphere was reduced to $9-40 \mathrm{~km}$ in areas that evolved into Late Permian and Mesozoic depocentres, whereas it retained a thickness of 40-90 km beneath slowly subsiding areas and persisting highs. There is no relationship between the degree of lithospheric thinning and the different Variscan tectonic units.

2) Following this Permo-Carboniferous thermal surge, the temperature of the asthenosphere returned rapidly to ambient levels during the late Early Permian. With this, re-equilibration of the lithosphere with the asthenosphere commenced and persisted during the Mesozoic, controlling the subsidence of a system of intracratonic thermal sag basins. As there is no clear relationship between Permo-Carboniferous troughs and the geometry of superimposed Late Permian to Mesozoic thermal sag basins, we conclude that PermoCarboniferous thermal thinning and delamination of the mantle lithosphere provided the principle driving mechanism for the subsidence of these intracratonic basins. Minor intra-Mesozoic tensional events hardly disturbed the asthenosphere-lithosphere system of the ECRIS area, except in its southern parts, which are superimposed on the shelves of the Alpine Tethys and the Pyrenean-Valais Ocean, and in the Roer Valley Graben, which is superimposed on the West Netherlands Basin. In the RRS area the lithosphere had re-equilibrated with the asthenosphere by end-Cretaceous times at depths of 100-120 km.

3) During the latest Cretaceous and Paleocene intraplate compressional stresses, projected from the evolving Alps and Pyrenees into their foreland, caused broad-scale lithospheric warping and basininversion in the ECRIS area. At the same time a system of not-very-active mantle plumes impinged on the foreland lithosphere, causing partial melting of its thermal boundary layer. In conjunction with the essentially contemporaneous impingement of the NE-Atlantic and Iceland plumes, this led to the gradual development of the upper asthenospheric $\mathrm{P}$ - and S-wave anomaly, which presently characterises Phanerozoic Europe, and related thermal weakening of the lithosphere.

4) ECRIS developed by passive rifting in the foreland of the Alps and Pyrenees in response to the build-up of a collision-relate intraplate compressional stress field that permutated in time. The late Eocene initial rifting phase of ECRIS, involving reactivation of preexisting Late Palaeozoic and Mesozoic crustal discontinuities, was controlled by northward-directed compressional stresses that built up owing to increasing collisional coupling of the evolving Pyrenean and Alpine orogenic wedges with their foreland. 
This stress field persisted during the Oligocene main rifting stage of ECRIS, but decayed with the endOligocene termination of crustal shortening in the Pyrenees. The Miocene to Recent evolution of ECRIS was governed by west- to northwest-directed compressional stresses originating at the Alpine collision zone. The RRS remained active until the present, whereas the grabens of the Massif Central and the Rhône Valley became inactive during the early Miocene. The stress field controlling on-going deformation of the RRS is compatible with the regional stress field of Western and Central Europe, which reflects a combination of Alpine collision-related and Atlantic ridge-push forces. The RRS is not characterised by an indigenous stress field.

5) Plume-related thermal thinning of the mantle-lithosphere, starting during the late Oligocene and intensifying during the Miocene and Plio-Pleistocene, is held responsible for the reduction of lithospheric thicknesses to $50-60 \mathrm{~km}$ beneath the Rhenish Massif and the Massif Central and their progressive uplift. Lithospheric folding, in response to the build-up of collisionrelated Alpine stresses at mantle-lithospheric levels, controlled the Miocene and younger uplift of the Burgundy transfer zone and the Vosges-Black Forest and Bohemian Massif arches. Lithospheric extension across ECRIS, not exceeding $7 \mathrm{~km}$ and tapering to zero at its northern end, played a secondary role in lithospheric thinning and partial melt extraction.

Acknowledgements This paper summarises the results of studies that were carried out by the authors and their colleagues in the course of the EUCOR-URGENT Project. For more extended discussions on the Late Palaeozoic-Mesozoic and the Cenozoic evolution of the lithosphere in the area of the Rhine Rift System we refer to Ziegler et al. (2004) and Dèzes et al. (2004), respectively. We specifically acknowledge contributions by S.M. Schmid, M.E. Schumacher, S. Cloetingh and J-D. van Wees to our studies. P. Dèzes acknowledges financial support by the Swiss Federal Office for Education and Science via a University of Basel ELTEM grant. We thank an anonymous reviewer for his comments on our manuscript.

\section{References}

Achauer U, Masson F (2002) Seismic tomography of continental rifts revisited: from relative to absolute heterogeneities. Tectonophysics 358:17-37

Adamovic J, Coubal M (1999) Intrusive geometries and Cenozoic stress history of the northern part of the Bohemian Massif. GeoLines (Prague) 9:5-14

Ahorner L (1975) Present-day stress field and seismotectonic block movements along major fault zones in Central Europe. Tectonophysics 29:233-249

Ahorner L (1983) Historical seismicity and present-day microearthquake activity of the Rhenish Massif, Central Europe. In: Fuchs K, Von Gehlen K, Mälzer M, Murawski H, Semmel A (eds) Plateau uplift, the Rhenish Shield-a case history. Springer, Berlin Heidelberg New York, pp 198-221

Andeweg B (2002) Cenozoic tectonic evolution of the Iberian Peninsula, causes and effects of changing stress fields. Ph.D. Thesis Vrije Universiteit Amsterdam. Netherlands Research School of Sedimentary Geology Publ 2020101:178 p
Ansorge J, Blundell D, Müller St (1992) Europe's lithosphereseismic structure. In: Blundell D, Freeman R, Müller St. (eds) A continent revealed, the European Geotraverse. Cambridge University Press, Cambridge, pp 33-69

Artemieva IM, Mooney WD (2001) Thermal thickness and evolution of Precambrian lithosphere: a global study. J Geophys Res 106(B8):16387-16414

Arthaud F, Matte P (1977) Late Paleozoic strike-slip faulting in Southern Europe and North Africa: results of a right-lateral shear between the Appalachians and Urals. Geol Soc Am Bull 88:1305-1320

Babushka V, Plomerova J (1992) The lithosphere in central Europe-seismological and petrological approach. Tectonophysics 207:141-163

Babushka V, Plomerova J (2001) Subcrustal lithosphere around the Saxothuringian-Moldanubian suture zone-a model derived from anisotropy of seismic wave velocities. Tectonophysics 332:185-199

Becker A (2000) The Jura Mountains-an active foreland fold-andthrust belt? Tectonophysics 321:381-406

Benek R, Kramer W, McCann T, Scheck M, Negendank JFW, Kronich D, Huebscher H-D, Bayer U (1996) Permo-Carboniferous magmatism of the Northeast German Basin. Tectonophysics 266:379-404

Bergerat F (1977) La fracturation de l'avant-pays Jurassien entre la fosse de la Saône et du Rhin, analyse et essai d'interpretation dynamique. Rev Géogr Phys Géol Dynam (2)XIX(4):325-338

Bergerat F (1987) Stress fields in the European platform at the time of Africa-Eurasia collision. Tectonics 6:99-132

Bergerat F, Mugnier J-L, Guellec S, Trufferrt C, Cazes M, Damotte B, Roure F (1990) Extensional tectonics and subsidence of the Bresse basin: an interpretation from ECORS data. Mém Soc géol France 156:145-156

Berggren WA, Kent DV, Swisker III CC, Aubrey MP (1995) Revised Cenozoic geochronology and chronostratigraphy. In: Berggren WA, Kent DV, Aubray MP, Hardenbol J (eds) Geochronology, time scales and global stratigraphy correlation. Soc Econ Paleont Mineral Spec Publ 54(19):129-212

Bessereau G, Guillocheau F, Huc A-Y (1995) Source rock occurrence in a sequence stratigraphic framework: the example of the Lias of the Paris Basin. In: Huc A-Y (ed) Paleogeography, paleoclimate, and source rocks. Am Assoc Petrol Geol, Studies in Geology 40:273-301

Bijwaard H, Spakman W (1999) Tomographic evidence for a narrow mantle plume below Iceland. Earth Planet Sci Lett 166:121-126

Blès J-L, Gros Y (1991) Stress field changes in the Rhone Valley from the Miocene to the present. Tectonophysics 194:265-277

Boenigk W (2002) The Pleistocene drainage pattern in the Lower Rhine basin. Neth J Geosci 81:201-209

Boigk H, Schöneich H (1970) Die Tiefenlage der Permbasis im nördlichen Teil des Oberrheingrabens. In: Illies JH, Mueller St. (eds) Graben problems. Schweizerbart'sche Verlagsbuchhandlung Stuttgart. International Upper Mantle Project, Sci Rept 27:48-55

Bonin B (1990) From orogenic to anorogenic settings: evolution of granitoids suits after a major orogenesis. Geol J 25:260-270

Bonin B, Brändlin P, Bussy F, Desmons J, Eggenberger U, Finger F, Graf K, Marro C, Mercolli L, Oberhänsli R, Ploquin A, von Quadt A, von Raumer J, Schaltegger U, Steyer HP (1993) Late Variscan magmatic evolution of the Alpine basement. In: von Raumer JF, Neubauer F (eds) Pre-Mesozoic geology of the Alps. Springer, Berlin Heidelberg New York, pp 171-201

Bousquet R, Goffé B, Henry P, Chopin Ch (1997) Kinematic, thermal and petrological model of the Central Alps: Lepontine metamorphism in the upper crust and eclogitisation of the lower crust. Tectonophysics 273:105-127

Breitkreuz C, Kennedy A (1999) Magmatic flare-up at the Carboniferous/Permian boundary in the NE German basin revealed by SHRIMP zircon ages. Tectonophysics 302:307-326

Brun J-P, Gutscher M-A, DEKORP-ECORS team (1992) Deep crustal structure of the Rhine Graben from DEKORP-ECORS seismic reflection data. Tectonophysics 208:39-147 
Brunnacker K, Boenigk W (1983) The Rhine Valley between the Neuwied Basin and the Lower Rhenish Embayment. In: Fuchs K, von Gehlen K, Mälzer M, Murawski H, Semmel A (eds) Plateau Uplift, The Rhenish Shield - a case history. Springer, Berlin Heidelberg New York, pp 62-72

Bucher S, Schmid SM, Bousquet R, Fügenschuh B (2003) Late-stage deformation in a collisional orogen (Western Alps): nappe refolding, back-thrusting or normal faulting? Terra Nova 15:109-117

Burg J-P, van den Driesschen J, Brun J-P (1994) Syn- to postthickening extension in the Variscan Belt of Western Europe: modes and structural consequences. Géologie de la France 3:33-51

Burkhard M, Sommaruga A (1998) Evolution of the western Swiss Molasse basin: structural relations with the Alps and the Jura belt. In: Mascle A, Puigdefàbregas C, Luterbacher HP, Fernandez M (eds) Cenozoic Foreland Basins of Western Europe. Geol Soc London, Spec Publ 134:279-298

Chauve P, Martin J, Petitjean E, Sequeiros F (1988) Le chevauchement du Jura sur la Bresse. Données nouvelles et réinterpretation des sondages. Bull Soc géol France 8(IV):861-870

Cloetingh S (1988) Intra-plate stresses: a new element in basin analysis. In: Kleinspehn KL, Paola C (eds) Frontiers in sedimentary geology - new perspectives in basin analysis. Springer, Berlin Heidelberg New York, pp 205-230

Cortesogno L, Dallagiovanna G, Gaggero L, Oggiano G, Ronchi A, Seno S, Vanossi M (1998) The Variscan post-collisional volcanism in Late Carboniferous-Permian sequences of Ligurian Alps, Southern Alps and Sardinia (Italy): a synthesis. Lithos 45:305-328

Coulon M (1992) La distension oligocène dans le nord-est du bassin de Paris (perturbation des directions d'extension et distribution des stylolites). Bull Soc géol France 163:531-540

Coward MP (1993) The effects of Late Caledonian and Variscan escape tectonics on basement structure, Paleozoic basin kinematics and subsequent Mesozoic basin development in NW Europe. In: Parker J (ed) Petroleum geology of Northwest Europe; Proceedings of the 4th conference. Geol. Soc., London, pp 1095-1108

Davies JH, von Blanckenburg F (1995) Slab breakoff: a model of lithosphere detachment and its test in the magmatism and deformation of collisional orogens. Earth Planet Sci Lett 129:85-102

Deichmann N, Ballarin Dolfin D, Kastrup U (2000) Seismizität der Nord- und Zentralschweiz. NAGRA Technischer Bericht, Wettingen, 00-05, $93 \mathrm{p}$

Delouis B, Haessler H, Cisternas A, Rivera L (1993) Stress tensor determination in France and neighbouring regions. Tectonophysics 211:413-437

Dèzes P, Ziegler PA (2002) Moho depth map of Western and Central Europe. World Wide Web Address: http://www.unibas.ch/eucor-urgent

Dèzes P, Schmid SM, Ziegler PA (2004) Evolution of the European Cenozoic Rift System; interaction of the Pyrenean and Alpine orogens with the foreland lithosphere. Tectonophysics 389 $(1-2): 1-33$

Eisbacher GH, Lüschen E, Wickert F (1989) Crustal-scale thrusting and extension in the Hercynian Schwarzwald and Vosges, Central Europe. Tectonics 8:1-21

Franke W (2000) The Mid-European segment of the Variscides: tectonostratigraphic units, terrane boundaries and plate tectonic evolution. In: Franke W, Haak V, Oncken O, Tanner D (eds) Orogenic processes: quantification and modelling in the Variscan Belt. Geol Soc London, Spec Publ 179:35-62

Fügenschuh B, Schmid SM (2003) Late stage of deformation and exhumation of an orogen constrained by fission-track data: a case study in the Western Alps. Geol Soc Am Bull 115:1425-1440

Garcia-Castellanos D, Cloetingh S, van Balen R (2000) Modelling the middle Pleistocene uplift in the Ardennes-Rhenish Massif: thermo-mechanical weakening under the Eifel. Global Planet Changes 27:39-52

Geluk MC, Duin EJT, Dusar M, Rijkers RHB, van den Berg MW, van Rooijen P (1994) Stratigraphy and tectonics of the Roer Valley Graben. Geol Mijnb 73:129-141
Giamboni M, Ustaszewski K, Schmid SM, Schumacher M, Wetzel A (2003) Plio-Pleistocene deformation in the southern Upper Rhine Graben area: geological and geomorphological evidence for on-going transpressive reactivation of Paleozoic and Paleogene faults. Int J Earth Sci 93:207-223

Giamboni M, Wetzel A, Nivière B, Schumacher M (2004) PlioPleistocene folding in the southern Rhinegraben recorded by the evolution of the drainage network (Sundgau area; northwestern Switzerland and France). Eclogae geol Helv 97:17-31

Giglia G, Capponi G, Crispini L, Piazza M (1996) Dynamics and seismotectonics of the West-Alpine arc. Tectonophysics 267:143-175

Goes S, Spakman W, Bijwaard H (1999) A lower mantle source for Central European volcanism. Science 286:1928-1930

Goes S, Loohuis JJP, Wortel MIR, Govers R (2000a) The effect of plate stresses and shallow mantle temperatures on the tectonics of northwestern Europe. Global Planet. Change 27:23-38

Goes S, Govers R, Vacher P (2000b) Shallow mantle temperatures under Europe from P and S wave tomography. J Geophys Res 105:11,153-11,169

Goggin V, Jaquin T, Gaulier JM (1997) Three-dimensional accommodation analysis of the Triassic in the Paris Basin: a new approach in unravelling the basin evolution with time. Tectonophysics 281:205-232

Gradstein FM, Ogg J (1996) A Phanerozoic time scale. Episodes 19:3-5

Granet M, Wilson M, Achauer U (1995) Imaging mantle plumes beneath the French Massif Central. Earth Planet Sci Lett 136:199-203

Guellec S, Mugnier J-L, Tardy M, Roure F (1990) Neogene evolution of the western Alpine foreland in the light of the ECORS data and balance cross-section. Mém Soc géol France 156:165-184

Hahn A, Wonik T (2002) Verteilung der Magnetisierung in der Erdkruste im Gebiet Deutschlands. Geol Jb, Sh Reihe E, Heft SE $2,35 \mathrm{p}$

Haq BU, Hardenbol J, Vail P (1988) Mesozoic and Cenozoic chronostratigraphy and eustatic cycles. Soc Econ Paleont Mineral Spec Publ 42:71-108

Hegner F, Chen F, Hann HP (2001) Chronology of basin closure and thrusting in the internal zone of the Variscan belt in the Schwarzwald, Germany: evidence from zircon ages, trace element geochemistry, and $\mathrm{Nd}$ isotopic data. Tectonophysics 332:169-184

Henk A (1993) Late orogenic basin evolution in the Variscan Internides, the Saar-Nahe Basin, Southwest Germany. Tectonophysics 223:273-290

Heumann G, Litt Th (2002) Stratigraphy and paleoecology of the Late Pliocene and Early Pleistocene in the open-cast mine Hambach (Lower Rhine Basin). Neth J Geosci 81:193-199

Hinzen K-G (2003) Stress field in the Northern Rhine area, Central Europe, from earthquake fault-plane solutions. Tectonophysics 377:325-356

Hoernle K, Zhang Yu-S, Graham D (1995) Seismic and geochemical evidence for large-scale mantle upwelling beneath the eastern Atlantic and western and central Europe. Nature London 374:34-39

Illies JH, Baumann H, Hoffers B (1981) Stress pattern and strain release in the Alpine foreland. Tectonophysics 71:157-172

Jouanne F, Ménard G, Darmendrail X (1995) Present-day vertical displacements in the north-western Alps and southern Jura: data from levelling comparisons. Tectonics 14:606-616

Jouanne F, Genaudeau N, Ménard G, Darmendrail X (1998) Estimating present-day displacement fields and tectonic deformation in active mountain belts: an example from the Chartreuse Massif and the southern Jura Mountains, western Alps. Tectonophysics 296:403-419

Judenherc S, Granet M, Brun J-P, Poupinet G, Plomerova J, Mocquet A, Achauer U (2002) Images of lithospheric heterogeneities in the Armorican segment of the Hercynian Range in France. Tectonophysics 358:121-134

Jung S (1999) The role of crustal contamination during evolution of continental rift-related basalts, a case study from the Vogelsberg area Central Germany. GeoLines, Prague 9:48-58 
Keller J, Kramel M, Henjes-Kunst F (2002) ${ }^{40} \mathrm{Ar} /{ }^{39} \mathrm{Ar}$ single crystal dating of early volcanism in the Upper Rhine Graben and tectonic implications. Schweiz Mineral Petrogr Mitt 82:121-130

Klett M, Eichhorst F, Schäfer A (2002) Facies interpretation from well logs applied to the Tertiary Lower Rhine basin fill. Neth J Geosci 81:167-176

Kooi H, Cloetingh S, Burrus J (1992) Lithospheric necking and regional isostasy at extensional basins: Part 1 . Subsidence and gravity modelling with application to the Gulf of Lions margin (SE France). J Geophys Res 97:17553-17571

Korsch RJ, Schäfer A (1995) The Permo-Carboniferous Saar-Nahe Basin, South-west Germany and North-east France, basin formation and deformation in a strike-slip regime. Geol Rundsch 84:293-318

Lardeaux JM, Ledru P, Daniel I, Duchène S (2001) The Variscan French Massif Central - a new addition to the ultra-high pressure metamorphic "club": exhumation processes and geodynamic consequences. Tectonophysics 332:143-162

Laubscher HP (1986) The eastern Jura: relations between thinskinned and basement tectonics, local and regional. Geol Rundsch 75:535-553

Laubscher H (1992) Jura kinematics and the Molasse Basin. Eclogae geol Helv 85:653-675

Laubscher H (2003) The Miocene dislocations in the northern foreland of the Alps: oblique subduction and its consequences (Basel area, Switzerland-Germany). Jber Mitt oberrhein geol Ver N.F. 85:423-439

Le Pichon X, Henry P, Goffé B (1997) Uplift of Tibet: from eclogites to granulites - implications for the Andean Plateau and the Variscan Belt. Tectonophysics 273:57-76

Lenôtre N, Garnier T, Delfau M (1992) Mouvements verticaux actuels dans le sud-est du Massif Central. 14e RST, Toulouse, 13-14 April, 1992, 2 p (abstract)

Lickorish WH, Ford M (1998) Sequential restoration of the external Alpine Digne thrust system, SE France, constrained by kinematic data and synorogenic sediments. In: Mascle A, Puigdefàbregas C, Luterbacher HP, Fernandez M (eds) Cenozoic Foreland Basins of Western Europe. Geol Soc London, Spec Publ 134:189-211

Lippolt HJ (1983) Distribution of volcanic activity in space and time. In: Fuchs K, von Gehlen K, Mälzer M, Murawski H, Semmel A (eds) Plateau Uplift, The Rhenish Shield-a case history. Springer, Berlin Heidelberg New York, Heidelberg, New York, Tokyo, pp 112-120

Littke R, Bücker C, Hertle M, Karg H, Stroetmann-Heinen V, Oncken O (2000) Heat flow evolution, subsidence and erosion in the Rheno-Hercynian orogenic wedge of central Europe. In: Franke W, Haak V, Oncken O, Tanner D (eds) Orogenic processes: quantification and modelling in the Variscan Belt. Geol Soc, London, Spec Publ 179:231-255

de Lugt IR, van Wees JD, Wong ThE (2003) The tectonic evolution of the southern Dutch North Sea during the Paleogene: basin inversion in distinct pulses. Tectonophysics 373:141-159

Malkovsky M (1987) The Mesozoic and Tertiary basins of the Bohemian Massif and their evolution. Tectonophysics 137:31-42

Mälzer H, Hein G, Zippelt K (1983) Height changes in the Rhenish Massif: determination and analysis. In: Fuchs K, von Gehlen K, Mälzer M, Murawski H, Semmel A (eds) Plateau uplift, The Rhenish Shield - a case history. Springer, Berlin Heidelberg New York, pp 165-176

Martinod J, Jouanne F, Taverna J, Ménard G, Gamond J-F, Darmendrail X, Notter J-C, Basil C (1996) Present-day deformation of the Dauphiné Alpine and Subalpine massifs (SE France). Geophys J Int 127:189-200

Marx J, Huebscher H-D, Hoth K, Korich D, Kramer W (1995) Vulkanostratigraphie und Geochemie der Eruptivekomplexe. In: Plein E (ed) Norddeutsches Rotliegendbecken. Courier Forschungsinstitut Senkenberg 183:54-83

McKenzie DP (1978) Some remarks on the development of sedimentary basins. Earth Planet Sci Lett 40:25-32

Meissner R, Bortfeld RK (eds) (1990) DEKORP-Atlas, results of Deutsches Kontinentales Reflexionsseismisches Programm. Springer, Berlin Heidelberg New York, 18 p. and 80 plates
Meissner R, Rabbel W (1999) Nature of crustal reflectivity along the DEKORP profiles in Germany in comparison with reflection patterns from different tectonic units worldwide: a review. Pure Appl Geophys 156:7-28

Mengel K (1992) Evidence from xenoliths for the composition of the lithosphere. In: Blundell D, Freeman R, Müller St (eds) A continent revealed, the European Geotraverse. Cambridge University Press, Cambridge, pp. 91-102

Menning M (1995) A numerical time scale for the Permian and Triassic periods: an integrated time analysis. In: Scholle PA, Peryth TM, Ulmer-Scholle DS (eds) The Permian of Northern Pangea. Springer, Berlin Heidelberg New York, Vol. 1: pp. 7797

Menning M, Weyer D, Drozodzewski G, van Ameron HWJ, Wendt I (2000) A Carboniferous time scale 2000: discussion and use of geological parameters as time indicators from Central and Western Europe. Geol Jb A 156:3-44

Merle O, Michon L (2001) The formation of the West-European Rift: a new model exemplified by the Massif Central area. Bull Soc géol France 172:213-221

Merle O, Michon L, Camus G, de Goer A (1998) L'extension oligocène sur la transversale septentrionale du rift du Massif Central. Bull Soc géol France 109:615-626

Meyer W, Stets J (2002) Pleistocene to Recent tectonics in the Rhenish Massif (Germany). Neth J Geosci 81:217-221

Michon L, Merle O (2001) The evolution of the Massif Central rift: spatio-temporal distribution of the volcanism. Bull Soc géol France 172:201-211

Michon L, van Balen RT, Merle O, Pagnier H (2003) The Cenozoic evolution of the Roer Valley rift system integrated at a European scale. Tectonophysics 367:101-126

Müller B, Wehrle V, Zeyen H, Fuchs K (1997) Short-scale variations of tectonic regimes in the western European stress province north of the Alps and Pyrenees. Tectonophysics 275:199-219

Müller WH, Naef H, Graf HR (2002) Geologische Entwicklung der Nordwestschweiz, Neotektonik und Langzeitszenarien Zürcher Weinland. NAGRA Technischer Bericht, Wettingen, 99-08:237 p

Neumann E-R,Olsen KH Baldridge S (1995) The Oslo Rift. In: Olsen KH (ed) Continental rifts: evolution, structure, tectonics. Elsevier, Amsterdam, pp 345-373

Neumann E-R, Wilson M, Heeremans M, Spencer EA, Obst K, Timmerman MJ, Kirstein L (2004) Carboniferous-Permian rifting and magmatism in southern Scandinavia, the North Sea and northern Germany: a review. In: Wilson M, Neumann E-R, Davies GR, Timmerman MJ, Heeremans M, Larsen BT (eds) Permo-Carboniferous Magmatism and Rifting in Europe. Geol Soc, London, Spec Publ 223:11-40

Oncken O, Plesch A, Weber J, Ricken W, Schrader S (2000) Passive margin detachment during arc-continent collision (Central European Variscides) In: Franke W, Haak V, Oncken O, Tanner D (eds) Orogenic processes: quantification and modelling in the Variscan Belt. Geol Soc, London Spec Publ 179:199-216

Philippe Y, Colletta B, Deville E, Mascle A (1996) The Jura foldand-thrust belt: a kinematic model based on map-balancing. In: Ziegler PA, Horvàth F (eds) Structure and prospects of Alpine basins and forelands. Peri-Tethys Mem. 2. Mém. Mus. natn. Hist. nat., Paris, 170:235-261

Philippe Y, Deville E, Mascle A (1998) Thin-skinned inversion tectonics at oblique basin margins: example of the western Vercors and Chartreuse subalpine massifs (SE France). In: Mascle A, Puigdefàbregas C, Luterbacher HP, Fernandez M (eds) Cenozoic Foreland Basins of Western Europe. Geol Soc, London, Spec Publ 134:239-262

Plenefisch T, Bonjer K-P (1997) The stress field in the Rhine Graben area inferred from earthquake focal mechanisms and estimations of frictional parameters. Tectonophysics 275:71-97

Prijac C, Doin MP, Gaulier JM, Guillaucheau F (2000) Subsidence of the Paris Basin and its bearing on the late Variscan lithosphere evolution: a comparison between the Plate and Chablis models. Tectonophysics 323:1-38 
Prodehl C, Mueller St, Haak V (1995) The European Cenozoic rift system. In: Olsen KH (ed) Continental Rifts: Evolution, Structure, Tectonics. Elsevier, Amsterdam, Lausanne, New York, Developments in Geotectonics 25:133-212

von Raumer JE (1998) The Palaeozoic evolution in the Alps: from Gondwana to Pangea. Geol Rundsch 87:407-435

Ritter JRR, Jordan M, Christensen UR, Achauer U (2001) A mantle plume below the Eifel volcanic fields, Germany. Earth Planet Sci Lett 186:7-14

Roca E (2001) The Northwest Mediterranean Basin (Valencia Trough, Gulf of Lions, and Liguro-Provençal basins): structure and geodynamic evolution. In: Ziegler PA, Cavazza W, Robertson AHF, Crasquin-Soleau S (eds) Peri-Tethys Memoir 6: Peri-Tethyan Rift/Wrench Basins and Passive Margins. Mém. Mus. natn. Hist. nat., Paris, 186:617-706

Roll A (1979) Versuch einer Volumenbilanz des Oberrheingrabens und seiner Schultern. Geol. Jb. Reihe A, Heft 52:82 p

Roure F, Colletta B (1996) Cenozoic inversion structures in the foreland of the Pyrenees and Alps. In: Ziegler PA, Horvàth F (eds) Structure and Prospects of Alpine Basins and Forelands. Peri-Tethys Mem. 2, Mém. Mus. natn. Hist. nat., Paris, 170:173-209

Roure F, Brun J-P, Colletta B, Vially R (1994) Multiphase extensional structures, fault reactivation, and petroleum plays in the Alpine foreland Basin of southeastern France. In: Mascle A (ed) Hydrocarbon and Petroleum Geology of France. Springer, Berlin Heidelberg New York, Europ. Assoc. Petrol. Geosci., Spec. Publ. 4:245-268

Royden L, Keen CE (1980) Rifting process and thermal evolution of the continental margin of eastern Canada determined from subsidence curves. Earth Planet Sci Lett 51:343-361

Sanchis E, Séranne M (2000) Structural style and tectonic evolution of a polyphase extensional basin of the Gulf of Lion passive margin: the Tertiary Alès basin, southern France. Tectonophysics 322:219-242

Schäfer F, Oncken O, Kemnitz H, Romer R (2000) Upper-plate deformation during collisional orogeny: a case study from the German Variscides (Saxo-Thuringian Zone). In: Franke W, Haak V, Oncken O, Tanner D (eds) Orogenic Processes: Quantification and Modelling in the Variscan Belt. Geol Soc, London, Spec Publ 179:281-302

Schmid SM, Kissling E (2000) The arc of the western Alps in the light of geophysical data on deep crustal structure. Tectonics 19:62-85

Schmid SM, Pfiffner OA, Froitzheim N, Schönborn G, Kissling E (1996) Geophysical-geological transect and tectonic evolution of the Swiss-Italian Alps. Tectonics 12:1036-1064

Schmid SM, Fügenschuh B, Kissling E, Schuster R (2004) Tectonic map and overall architecture of the Alpine orogen. Eclog geol Helv 97:93-117

Schumacher ME (2002) Upper Rhine Graben: the role of preexisting structures during rift evolution. Tectonics 21:10.1029/ 2001TC900022 (6-1-6-17)

Sclater JG, Christie PAF (1980) Continental stretching, an explanation of the post-Mid-Cretaceous subsidence of the Central North Sea basin. J Geophys Res 85:3711-3739

von Seckendorff V, Arz C, Lorenz V (2004) Magmatism of the late Variscan intramontane Saar-Nahe Basin (Germany): a review, In: Wilson M, Neumann E-R, Davies GR, Timmerman MJ, Heeremans M, Larsen BT (eds) Permo-Carboniferous Magmatism and Rifting in Europe. Geol Soc, London, Spec Publ 223:361-391

Séranne M (1999) The Gulf of Lion continental margin (NW Mediterranean) revisited by IBS: an overview. In: Durand B, Jolivet L, Horvàth F, Séranne $M$ (eds) The Mediterranean Basins: Tertiary Extension within the Alpine Orogen. Geol. Soc., London, Spec. Publ. 156:15-36

Seyferth M, Henk A (2000) Deformation, metamorphism and exhumation: quantitative models for a collision zone in the Variscides. In: Franke W, Haak V, Oncken O, Tanner D (eds) Orogenic Processes: Quantification and Modelling in the Variscan Belt. Geol Soc, London Spec Publ 179:217-230
Sissingh W (1998) Comparative tertiary stratigraphy of the Rhine Graben, Bresse Graben and Molasse Basin: correlation of Alpine foreland events. Tectonophysics 300:249-284

Sissingh W (2001) Tectonostratigraphy of the West Alpine Foreland: correlation of tertiary sedimentary sequences, changes in eustatic sea-level and stress regimes. Tectonophysics 333:361400

Sissingh W (2003) Tertiary paleogeographic and tectonostratigraphic evolution of the Rhenish Triple Junction. Palaeogeogr Palaeoclim Palaeoecol 196:229-263

Sobolev SV, Zeyen H, Granet M, Achauer U, Bauer C, Werling F, Altherr R, Fuchs K (1997) Upper mantle temperatures and lithosphere-asthenosphere system beneath the French Massif Central constrained by seismic, gravity, petrologic and thermal observations. Tectonophysics 275:143-164

Stampfli GM (1993) Le Briançonnais, terrain exotique dans les Alpes? Eclog geol Helv 86:1-45

Stampfli GM, Mosar J, Marquer D, Marchant R, Baudin T, Borel $G$ (1998) Subduction and obduction processes in the Alps. Tectonophysics 296:159-204

Stampfli GM, Mosar J, Favre P, Pillevuit A, Vannay J-C (2001) Permo-Mesozoic evolution of the western Tethys realm: the Neo-Tethys East-Mediterranean connection. In: Ziegler PA, Cavazza W, Robertson AHF, Crasquin-Soleau S (eds) PeriTethys Mem. 6: Peri-Tethyan Rift/Wrench Basins and Passive Margins. Mém. Mus. natn. Hist. nat. 186:51-108

Stollhofen H, Stanistreet IG (1994) Interaction between bimodal volcanism, fluvial sedimentation and basin development in the Permo-Carboniferous Saar-Nahe Basin (South-West Germany). Basin Res 6:245-267

Thomson SN, Zeh A (2000) Fission-track thermochronology of the Ruhla crystalline complex: new constraints on the post-Variscan thermal evolution of the NW Saxo-Bohemian Massif. Tectonophysics 324:17-35

Ulrych J, Pivec E, Lang M, Balogh K, Kropacek V (1999) Cenozoic intraplate volcanic rocks series of the Bohemian Massif: a review. GeoLines Prague 9:123-129

Vanderhaeghe O, Teyssier C (2001) Partial melting and flow of orogens. Tectonophysics 342:451-472

Vergés,J, García-Senez J (2001) Mesozoic evolution and Cainozoic inversion of the Pyrenean rift. In: Ziegler PA, Cavazza W, Robertson AHF, Crasquin-Soleau S (eds) Peri-Tethys Mem. 6: Peri-Tethyan Rift/Wrench Basins and Passive Margins. Mém Mus natn Hist nat 186:187-212

Vigneresse JL (1999) Intrusion level of granitic massifs along the Hercynian belt: balancing the eroded crust. Tectonophysics 307:277-295

Villemin T, Alvarez F, Angelier J (1986) The Rhine-graben, extension, subsidence and shoulder uplift. Tectonophysics 128:47-59

Weber K (1995a) Structural relationship between Saar-Nahe Basin, Odenwald, and Spessart Mts. In: Dallmeyer RD, Franke W, Weber K (eds) Pre-Permian geology of central and eastern Europe. Springer, Berlin Heidelberg New York, pp 182-185

Weber K (1995b) The Saar-Nahe Basin. In: Dallmeyer RD, Franke W, Weber K (eds) Pre-Permian geology of central and eastern Europe. Springer, Berlin Heidelberg New York, pp 186-189

van Wees J-D, Stephenson RA (1995) Quantitative modelling of basin and rheological evolution of the Iberian Basin (Central Spain): implications for lithosphere dynamics of intraplate extension and inversion. Tectonophysics 252:163-178

van Wees J-D, de Jong K, Cloetingh S (1992) Two-dimensional P-T-t modelling and dynamics of extension and inversion in the Betic Zone (SE Spain). Tectonophysics 203:305-324

van Wees J-D, Stephenson RA, Stovba SM, Shymanovski S (1996) Tectonic variation in the Dniepr-Donets Basin from automatic modelling of backstripped subsidence curves. Tectonophysics 268:257-280

van Wees J-D, Stephenson RS, Ziegler PA, Bayer U, McCann T, Dadlez R, Gaupp R, Nerkiewicz M, Bitzer F, Scheck M (2000) On the origin of the Southern Permian Basin, Central Europe. Mar Petrol Geol 17:43-59 
Wetzel A, Allenbach R, Allia V (2003) Reactivated basement structures affecting the sedimentary facies in a tectonically "quiescent" epicontinental basin: an example from NW Switzerland. Sediment Geol 157:153-172

Wilson M, Rosenbaum JM, Dunworth EA (1995) Melilites: partial melts of the thermal boundary layer?. J Petrol 32:181-196

Zeh A, Brätz H (2004) Timing of Upper Carboniferous-Permian horst-basin formation and magmatism in the NW Thuringian Forest, central Germany: a review. In: Wilson M, Neumann E-R, Davies GR, Timmerman MJ, Heeremans M, Larsen BT (eds) Permo-Carboniferous Magmatism and Rifting in Europe. Geol Soc, London, Spec Publ 223:319-334

Ziegler PA (1988) Evolution of the Arctic-North Atlantic and the Western Tethys. Am Assoc Petrol Geol Mem 43:198

Ziegler PA (1989) Evolution of Laurussia, a study in Late Palaeozoic plate tectonics. Kluver Acad. Publ., Dordrecht, 102 p. 14 plates

Ziegler PA (1990) Geological Atlas of Western and Central Europe, 2nd edn. Shell Internat. Petrol. Mij., dist. Geol. Soc. Publ. House, Bath, 239 p. 56 encl.

Ziegler PA (1994) Cenozoic rift system of western and central Europe: an overview. Geol Mijnb 73:99-127

Ziegler PA, Dèzes P (2005) Crustal evolution of western and central Europe. In: Gee D, Stephenson R (eds) European lithosphere dynamics. Mem Geol Soc London (submitted)

Ziegler PA, Stampfli GM (2001) Late Palaeozoic-Early Mesozoic plate boundary reorganization: collapse of the Variscan orogen and opening of Neotethys. In: Cassinis G (ed) Permian continental deposits of Europe and other areas. Regional reports and Correlations. Natura Bresciana Ann Mus Civ Sc Nat, Brescia Monogr N 25:17-34
Ziegler PA, Cloetingh S, van Wees J-D (1995) Dynamics of intraplate compressional deformation: the Alpine foreland and other examples. Tectonophysics 252:7-59

Ziegler PA, van Wees J-D, Cloetingh S (1998) Mechanical controls on collision-related compressional intraplate deformation. Tectonophysics 300:103-129

Ziegler PA, Cloetingh S, Guiraud R, Stampfli GM (2001) PeriTethyan platforms: constraints on dynamics of rifting and basin inversion. In: Ziegler PA, Cavazza W, Robertson AHF, Crasquin-Soleau S (eds) Peri-Tethys Mem. 6: Peri-Tethyan Rift/ Wrench Basins and Passive Margins. Mém Mus natn Hist nat 186:9-49

Ziegler PA, Bertotti G, Cloetingh S (2002) Dynamic processes controlling foreland development: the role of mechanical (de)coupling of orogenic wedges and forelands. In: Bertotti G, Schulmann K, Cloetingh S (eds) Continental Collision and the Tectono-Sedimentary Evolution of Forelands. Europ Geophys Soc Stephan Mueller Spec Publ 1:29-91

Ziegler PA, Schumacher ME, Dèzes P, van Wees J-D, Cloetingh S (2004) Post-Variscan evolution of the lithosphere in the Rhine Graben area: constraints from subsidence modelling. In: Wilson M, Neumann E-R, Davies GR, Timmerman MJ, Heeremans M, Larsen BT (eds) Permo-Carboniferous Magmatism and Rifting in Europe. Geol Soc, London, Spec Publ 223:289-317

Zielhuis A, Nolet G (1994) Deep seismic expression of an ancient plate boundary in Europe. Science 265:79-81

Zijerveld L, Stephenson R, Cloetingh S, Duin E, van den Berg MW (1992) Subsidence analysis and modelling of the Roer Valley Graben (SE Netherlands). Tectonophysics 208:159-171 